\title{
Landscape Connectivity Approach in Oceanic Islands by Urban Ecological Island Network Systems with the Case Study of Santa Cruz Island, Galapagos (Ecuador)
}

\author{
Verónica Lorena Andrade Sierra, Xuan Feng* \\ Architecture Department, School of Design, Shanghai Jiao Tong University, Shanghai, China \\ Email: vlas@sjtu.edu.cn, *lionxf@sjtu.edu.cn
}

How to cite this paper: Sierra, V. L. A., \& Feng, X. (2018). Landscape Connectivity Approach in Oceanic Islands by Urban Ecological Island Network Systems with the Case Study of Santa Cruz Island, Galapagos (Ecuador). Current Urban Studies, 6, 573-610. https://doi.org/10.4236/cus.2018.64031

Received: November 23, 2018

Accepted: December 24, 2018

Published: December 27, 2018

Copyright $\odot 2018$ by authors and Scientific Research Publishing Inc. This work is licensed under the Creative Commons Attribution International License (CC BY 4.0).

http://creativecommons.org/licenses/by/4.0/ (c) (i) Open Access

\begin{abstract}
The oceanic islands are well known for their high biodiversity where the dynamic integration of the ecosystems inside the populated islands is such as a living laboratory of ecological and social relations of interdependence. Oceanic islands are experimenting significant pressure on their ecosystems. Habitat fragmentation produces poor spatial connectivity between protected areas and human settlements. The essence of the research approach is to develop a new framework of Oceanic Island Network System based on urban ecological networks in dealing with island connectivity issues space. This new urban ecological planning tool can help to generate an integrator balance by a physical linkage system in a socio-ecosystem island. Facilitating the territorial ordering based on the spatial and functional relations between ecological functions and urban structure through the island network system has not been analyzed yet as an essential resource for integrating the natural and human systems in oceanic islands. This paper presents a landscape theory connectivity analysis of the built space vs. the natural space of oceanic islands with the case study of Santa Cruz Island, Galapagos into the Pelican Way Watershed boundaries. In this context, spatial network elements are considered under land movement concept. The analysis is intended to determine the spatial elements interrelationships by socio-ecological networks establishing a new landscape system strategy. Additionally, it is valuable and necessary to establish a new concept of land use network for oceanic islands, such as a potential resource to generating a physical structure of environmental balance connectivity, which includes social needs and ecological potentialities for successful urban ecological conservation and development.
\end{abstract}




\section{Keywords}

Oceanic Island, Island Network System, Socio-Ecosystem, Santa Cruz Island, Pelican Bay Watershed

\section{Introduction}

The investigation began from understanding the oceanic island ecosystems. The island territories have crucial importance, such as natural laboratories of observation in real sceneries with many relations between nature and human systems. Oceanic islands give the opportunity to face problems, such as climate change, landscape fragmentation, biodiversity loss, and population issues directly. A significant threat to oceanic islands is continued urban growing without a planning strategy for oceanic island lands. Island land implies cycles, flows of energy, species behavior, and human influences. This spatial heterogeneity creates a dynamic island landscape with the necessity of connectivity between nature and human system.

In these last decades, the topic about interactions between human and nature into the landscape space shows a main importance for understanding the socio-ecological systems. Landscape manages the interactions between human space and nature space in different scales determined by the human activities and nature processes. Recently, researches about systems interactions in Oceanic Islands spaces from several authors such as: (Nunn et al., 1999; Kirch, 2009; Wong et al., 2005; Calado et al., 2014; Grydehoj \& Kelman, 2016), show the importance of relations between human and nature spaces, facing different urban challenges and species vulnerabilities. Topics established, such as human settlements, tourism, environment, disaster risk, culture, land and housing, planning and development among others. These topics allow exploring the role of urban planning and design as a tool for addressing these critical issues (UN-Habitat, 2015).

In spite of the advances in Islands systems, few studios about concrete alternatives for comprehensive landscape planning in the Urban Island territories have been conducted. In this way, analyses about different theories and methods conducted in this research began from Landscape Ecology connectivity as a vital element of landscape structure (Taylor et al., 1993), patches and structural components (Forman \& Godron, 1981), land mosaics theory (Forman, 1995), Urban Ecology (Forman, 2014). Additionally, the concept of ecological networks applied to the urban context (Cook, 2002), the island urbanism Hawai'i intervention (Connelly, 2008) and corridor island in Tenerife (Mejías, 2018). As a result, these main theories set the starting point to generate a new system of landscape connectivity in island territories.

The approach of the investigation is to generate connectivity of two different systems: social and ecological into the comprehension of their existence as a part of a large functioning system. The main socio-ecological territorial problem which has been given in urban land and therefore protected areas is the being boosted in 
the beginning. The appropriation of the Islands through a process of colonization without regulation after this poor land management attempts to effects of conservation without taking into account the social and economic interests of the development of the population. The appropriation of the islands through a process of colonization without regulation generates a dichotomy between conservation and development. Few studies about social-ecological relationships with real methodologies alternatives on comprehensive territorial planning have been developed to creating a dynamic system balance in islands territories.

The question is how to encompass both the inhabited areas and the protected areas and at the same time boost the development of human systems, generating a balanced integrator in a socio-island ecosystem. Develop complex systems balance interactions with a physical interconnected system network. Structuring element of the space has not been proposed as a strategy for urban development and ecological conservation adapted to the oceanic islands ecosystem dynamics.

Island Network System was established such as landscape strategy with a focus on the integrity of the network for an appropriate coexistence between natural and urban areas ecosystem. "The objective is to understand interrelationships of elements, the landscape scale network becomes the main, and more stable, structure" (Cook, 2000). Results in reasonable copy and apply the operating network of nature on human systems. "The concept of functionality in the natural network applied to the social system aims to achieve the promotion and consolidation of cooperative relations between elements of urban areas, the agricultural and the natural system of Galapagos" (DPNG, 2014). "The human system that occupies only $0.2 \%$ of the ecoregion exerts enough intense pressure on generating effects on ecological integrity and resiliency of all of the ecosystems" (DPNG, 2014). "This situation produced to the Unesco declared the Galapagos Islands in risk and place into the list of World Heritage in Danger in June 2007. From this event" (González et al., 2008) emphasizes the solutions to the present crisis will also require a fusion of biological and social considerations.

Ecological System conservation has to be equal in priority motivations such as understanding of social system also. "This controversy between an isolated (claimed by conservation advocates) vs. an increasingly open (demanded by residents and local authorities) archipelago lies at the base of most conflicts in Galapagos" (Ospina, 2006). It is necessary to recognize the ecosystems interdependence and must adopt a spatial approach to determine the balance between environmental protection and human development. Santa Cruz Island was selected such as a case study, with the specific area of Pelican Bay watershed in the reason this zone contains the most populated urban areas, also, the agricultural land and the Galapagos National Park (GNP).

\section{The General Situation of Oceanic Islands}

\subsection{Principal Characteristics}

The principal difference between continental islands and oceanic islands is that 
continental Islands are fragments of a larger landmass, here the number of species will tend to decline. "They are the products of volcanism or tectonic uplift or the result of organic reef growth upon foundations formed by the first two processes. In contrast, most continental islands were joined to other continental land masses in the past, having since become separate due to tectonics or sea level rise." (Paulay, 1994). Oceanic Islands never have contact by continental land territory masses.

Oceanic islands result from the volcanic eruptions, so the number of species increases. Additionally, the levels of endemism are consequently very high. "Because of isolation, biotic disharmony, and lack of competition, island biotas are characterized by high species-level endemism and vulnerability to invasive taxa" (Kirch, 2009). Additionally, "Oceanic islands are unusual in their isolation, well defined geographically and distinct boundaries. Islands are particular territories, 'pieces' of land bounded by the sea and frequently isolated about the mainland which can be perceived as self-contained systems" (Calado et al., 2014). Finally, the differences between oceanic and continental islands determine important environmental, geographical, climatic, biophysical and human settlements relations.

\subsection{Classification}

Islands are usually defined as a piece of land surrounded by water. The size factor is the most commonly used for classification. Islands are determined by the combinations of area and population. "Islands can be categorized by physical aspects such as latitude (tropical, temperate or Artic), underlying geology or island structure (continental islands and oceanic islands)" (Wong et al., 2005). In this way (Henderson, 2003) express : the sea-bound islands fall into two categories; continental and oceanic, and tectonic processes generate them in three ways, the third way is about oceanic islands, individual or archipelagos, develop as overlying plates move across 'hot spots' where thermal plumes reside in the upper mantle (e.g., Galapagos archipelago).Finally, the research focuses on small oceanic islands defined as those with approximately $10.000 \mathrm{~km}^{2}$ or less in surface and approximately 500.000 or fewer residents (Beller et al., 2004; Hess, 1990).

\subsection{Functions and Roles}

Island at finite land space structured by different cycles of energy interactions influenced by the human systems. "Due to their spatial benefits, small islands are becoming the focus of powerful efforts to envision new forms of urban sustainability" (Grydehoj \& Kelman, 2016). The territorial space determines the pressure on the land to satisfy the necessity of the population. Components as sun, rain, wind, soil, fresh water are part of the complexity of the island systems. "Both green and blue space play the same significant role in offering ecological shelters for wildlife, as well as social, recreational, educational and historical places for humans" (Xiu et al., 2016). Through the physical integration of human and nat- 
ural systems, allow the conservation of ecosystems and their biodiversity, in addition to maintaining the capacity to generate workflow services ecosystem for the well-being of the local population and tourists. Island scale implies work in the complexity of the systems. Understand the organizational patterns as pressure indicators which would allow evaluating the risk of the total insular space.

\section{Importance to Nature and Human System}

\subsection{Nature System}

\subsubsection{Species Adaptation and Evolution}

The isolation of oceanic islands presents a living laboratory to understanding the species adaptation, evolution. "Darwin, strongly seconded by Wallace, drew a clear distinction between continental shelf islands, where drowning of former land connections has to be considered, and oceanic islands, such as the Galapagos, built up as volcanic peaks from the sea floor." (Sauer, 1969). Oceanic islands, because of their spatiotemporal properties, provide the most promising arena to address this challenge.

Regular cycles of distributional change following colonization of islands have been proposed. "Species and the communities in which they live are dynamic entities, their existence, distribution, and abundance, dictated by evolutionary and ecological responses to both natural and anthropogenic environmental change" (Gillespie, 2007). The diversity in natural systems helps to establish conservation strategies and restoration efforts, incorporating the evolutionary and ecological dynamics in the spatial flux of the island environment.

\subsubsection{Climate Change}

Islands are high climate-sensitive as a result of their small size and isolation. Variability in climate can eliminate species into terrestrial and marine ecosystems. High or low temperatures influenced by the sea, for example, climatic variations observed in the islands are related to the El Nino Southern Oscillation (ENSO). "Sea level rise is one of the most significant impacts because which can produce inundation of coastal areas" (Noone, 2013) and "pressure on forest reserves due to loss of coastal agricultural land by salination and will lead to migration or loss of wildlife species" (Wong et al., 2005). The devastating effects of earthquakes, volcanic eruptions, tsunamis, tropical cyclones are more critical impacts on an island's systems.

\subsubsection{Biological Diversity Conservation}

Islands constitute ecological isolated from birth. "Island systems provide habitats for plant, animal, and microbial species inhabiting both marine and terrestrial environments. Together with geological features, these habitats have particular value due to their high endemism or their absence on nearby mainland areas, making islands important refuges for many species" (Wong et al., 2005). For example, the Galapagos is a rare remnant of a prehistoric pattern of global bio- 
logical diversity where great proportions of the world's distinctive and often bizarre species occurred on islands. "Darwin's finches, the giant tortoises, and many other groups are excellent examples of such evolutionary radiation, where one original species has evolved into a whole range of different forms in their island isolation" (CDF \& WWF, 2002).

Island biodiversity have faced severe effects from human activities, causing several problems such landscape fragmentation causing the loss of the biodiversity. Additionally, the introduction of invasive species, natural disturbances, and environmental disasters. Under those circumstances, biodiversity conservation has become a vital necessity in islands territories, while providing natural laboratories to adopt new strategies in the management and plan the ecosystems affected by human activities.

\subsection{Human-System}

\subsubsection{Island Land Use Management}

Pioneering human population introduced the cultural concepts of land use and ecosystem management, altering the fragile and isolated island ecosystems. "While the isolation of oceanic islands has made them living laboratories for understanding species adaptation and evolution, it has also made them extremely vulnerable to invasive species and other stresses" (Gillespie, 2007). Direct impacts such physical manipulation of landscapes occurred adjacent the indirect impacts which have been implicated plants and animals in ecological changes of the oceanic ecosystems. "Furthermore, on many islands, informal and unplanned peri-urban development is also becoming increasingly evident, further increasing the pressure on coasts" (Nunn et al., 1999), creating effects on native biota, deforestation, species loss, and resource decrease.

When people find the necessity to move into a new area, "they bring cognitive models of how a landscape should be managed, how it should look, and how it should be manipulated" (Kirch, 2009). The cognitive models of land use management include agriculture, concepts of land ownership and division. As a result, these land use concepts transformed islands into interconnected complex landscapes between society and nature called socio-ecosystems.

\subsubsection{Ecosystems Services}

Oceanic Islands are ecologically fragile and vulnerable. Their geographic isolation produces limited resources. The ecosystem service approach faces this problem with the purpose of maintaining the flow of services for biodiversity and human well-being. "Therefore, we do not advocate substituting biodiversity for ecosystem services as the primary goal of protected areas. However, we call for a broader and more adaptive social-ecological approach for protected areas and their surrounding landscapes that includes both the intrinsic value (i.e., biodiversity conservation) and the instrumental value (i.e., ecosystem services) of nature" (Palomo et al., 2014). 
The main approach for ecosystem services in island territories is creating support services that include processes such as nutrient cycles and soil formation. "Island systems provide important ecosystem services, such as biodiversity, fisheries, energy, fresh water, vegetation cover, traditional ecological knowledge, and tourism. Insularity leads to an obvious strengthening of the linkages between island ecosystem services and people" (Wong et al., 2005). Additionally, procurement services such as solar radiation, wind, rainfall. Regulations services such climate, food production, water cycle and finally social services such as tourism which creates recreational, educational, esthetics, spiritual, cultural heritage resources developing a sense of identity and belonging to a place.

\subsubsection{Socioeconomic Conditions}

The population is present in some oceanic islands; they have rich and diverse cultures with unique adaptation to the island's ecosystems. They developed ancestral techniques to manage the natural resources, on the contrary, creating pressures and affectations to the environment. Island isolation, small size, and limited natural resources create specific economic conditions. "On most islands, especially small oceanic islands, fishing has always represented an essential source of animal protein and an important economic activity" (Calado et al., 2014). "For many islands, and especially small oceanic islands and island states, fish provide an almost indispensable source of animal protein" (Wong et al., 2005). However, the limited diversification economic produce a vast range of emigration special for young people and the lack of qualified professional groups. Island's unemployment continues to be a significant concern in the territory.

Mostly the tourism factor came to be the first economic motor of the islands. Tourism resources as biodiversity, natural sites visit, historical, architectural and archaeological features became to increase the touristic attractions from oceanic islands. "The growing importance of nature tourism surely is a positive factor, with a huge potential for biodiversity conservation and to promote sustainable use of natural resources. However, tourism development must be carefully planned and managed to avoid the degradation and destruction of natural and cultural heritage" (Calado et al., 2014).

\section{Urban Ecological Landscape Theories for Connectivity Approach}

\subsection{Related to Urban Spaces}

\subsubsection{Island Urbanism Theory ${ }^{1}$}

Live into an isolated archipelago where the issues of fragmented land use give the opportunity to develop a conceptual plan for rebuilt connections between urban development and the natural systems. Items as population growth, food production, and conservation areas are analyzing. The necessity of the islands to ${ }^{1}$ This point analyzes the theory from (Connelly, 2008) Hawaiian Islands Vision, developed for understand the environmental degradation experimented in these islands. The proposal is to generate a new Island Urbanism Concept for keep the health of world ecosystems. 
import energy and food resources creates more pressure on the conservations lands and increase on the life cost.

The importance of the communities and their local resources and ecologies is determined as the structure for the land use system. According to (Connelly, 2008), the Hawai'i island territory is divided into urban, agriculture and conservation districts, creating separation and reinforcing the demand for goods and services from the continental land. Problems as local food security, saving agricultural lands, protection of water resources followed a wrong system designed for continental land, not for volcanic islands.

The watershed represents the central organizing element of urbanization in volcanic islands. Watershed is an energy resource, cycles of flows. The idea of reorienting development around streams and watersheds engages the flow of resources and information forming a new technology system. This system is the recognition of the traditional system from indigenous land management practices. Also, the system recognizes the difference between continental and oceanic notions of time. "For example, a continental notion of time perceives land as static or something that can be made static, while an oceanic notion of time accepts that land is moving, that it floats, and that it is something that all together has an agency of its own" (Connelly, 2008). These ideas determine the scales and durations of time for the spatial sequence of the watershed (Figure 1).

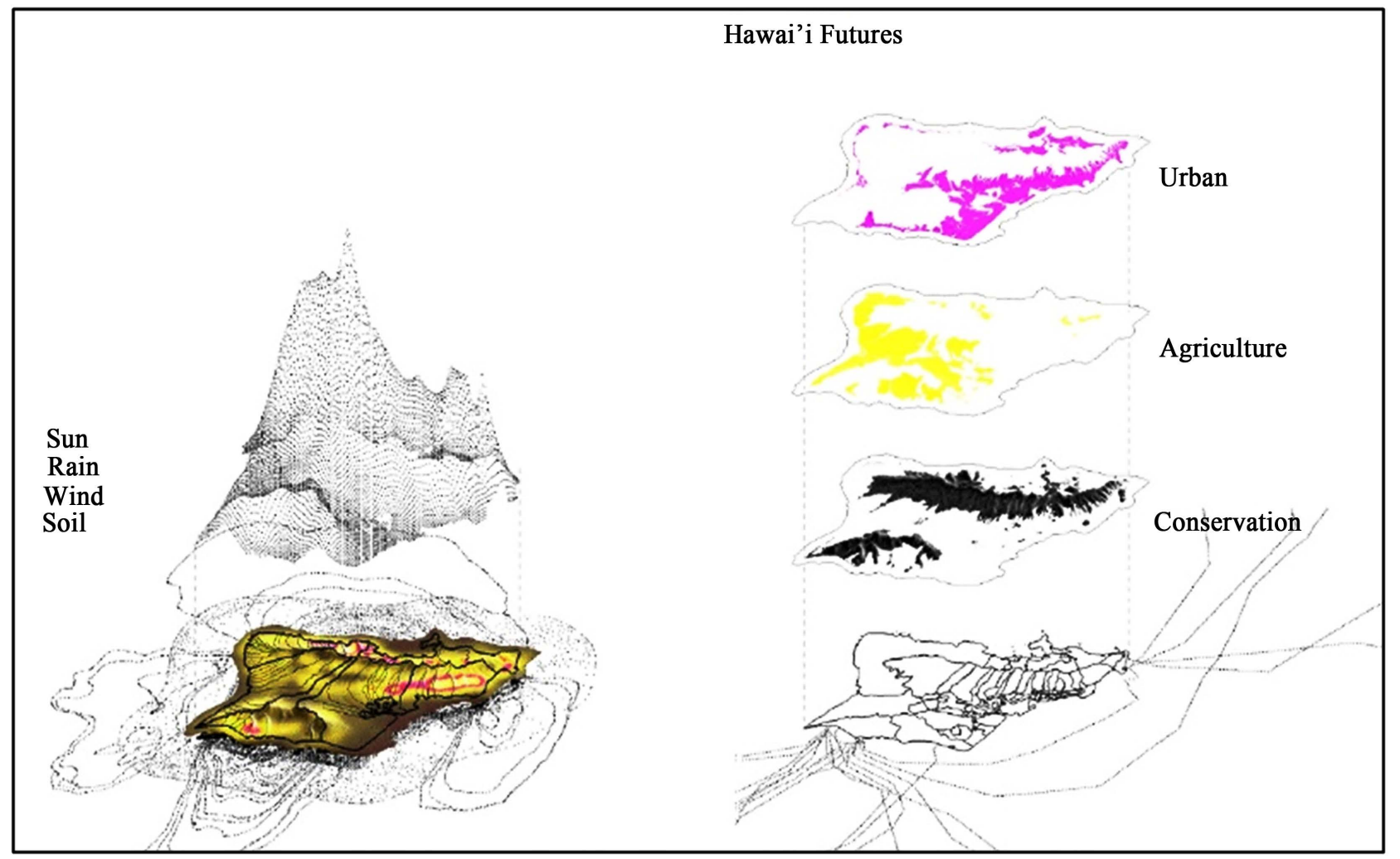

Figure 1. Island is shown as a living ecology (left) versus a static division of continent-based urbanism (right). From Connelly (2008). 


\subsubsection{Urban System for Corridor Island}

In contrast to Island Urbanism theory by (Connelly, 2008), the urban system for corridor island developed by (Mejías, 2018) ${ }^{2}$ consider the protected areas such the static island for its natural characteristics without significant pressure from the urban development. On the other hand, the unprotected areas called the "dynamic island" because here the higher risk of urban development created a very fragmented landscape.

Two concepts the urban sprawl and the soil sealing determined the main problems to analyze into the island. The urban sprawl indicates the urban growth around the suburban areas in dispersed space. As a result, it generates problems about spatial distances between residential areas and central areas of goods and services, creating spaces of exclusion and inequality.

The objective is to find a solution for compactness, ways of integration, creating relations between development and agricultural areas. To resolve these problem concepts as an island, island risk and corridor island search to create an urban system for island corridor (Figure 2). According to (Mejías, 2018), the level of deconstruction allows creating new units of spatial reference marked by the number of components involved in the process. Finally, the Corridor Island is where the new strategies are implemented under the concept of permeability, connector, and balancer.

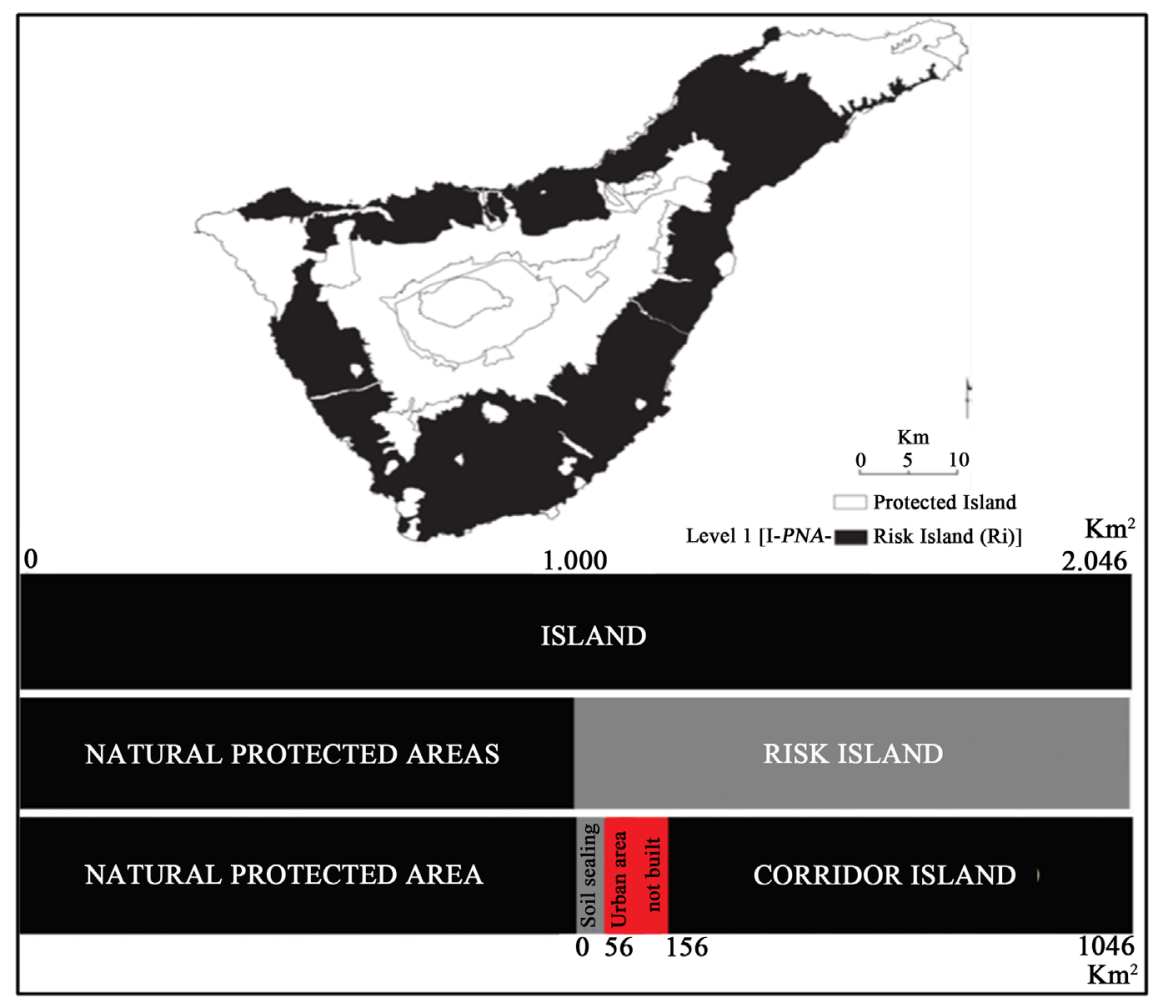

Figure 2. Risk island and proportional distribution of the types of the island. From Mejías (2018).

${ }^{2}$ Reference project about corridor island developed for the Tenerife Island by (Mejías, 2018). 


\subsubsection{Road Ecology}

"Road ecology explores and addresses the relationship between the natural environment and the road system" (Forman et al., 2002). The environmental impact of roads and vehicles on species and ecological systems increases year by year according to the urban development as a significant disturbance creating critic fragmentations on the landscape. Study the road location site, and segments give a road system which connects nodes and create links giving a road network. The network form determines the variability of connections between patches.

"Conceptual foundations of road ecology begin with water and water flows, followed by microclimate, wind, and atmospheric effect; vegetation and biodiversity; populations and wildlife; and finally, landscape ecology and habitat fragmentation" (Forman et al., 2002). Hydrology, microclimate, solar angle, road wind orientation patterns create microhabitats for plants and animals.

Two main factors are necessary for the implementation of the ecological roads, the understanding of the human flows and wildlife population dynamics (Figure 3). Priority projects could be considered the water movement and the reduction of wildlife road kills. At the same time, the vegetation and native plants in roadsides are essential points to take into account as programming road in urban ecological planning.

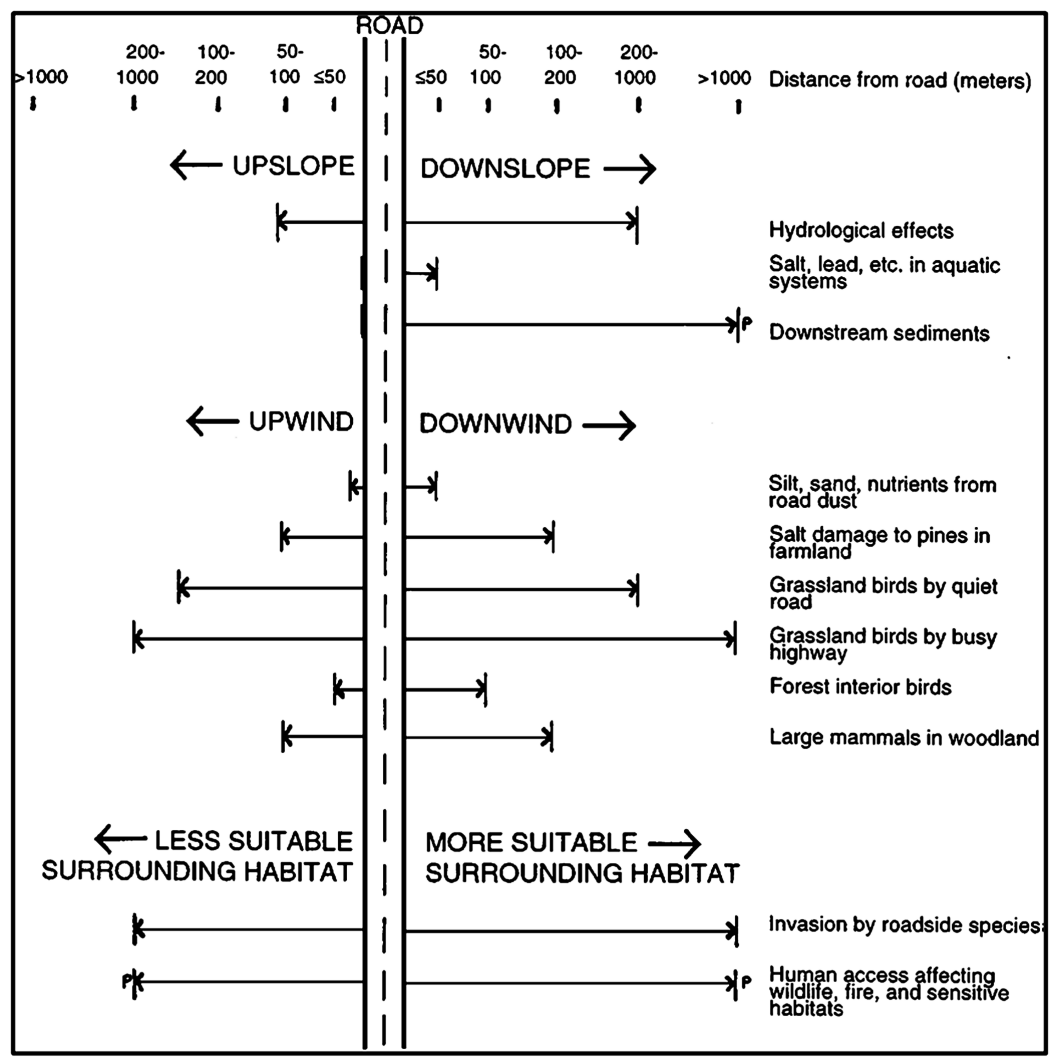

Figure 3. Road-effect zone defined by ecological effects. From Forman and Alexander, (1998). 


\subsubsection{Integration Island Land Use}

All theories considered give analyzes about the necessity to integrate urban zones and natural elements in one structure land use space. Two mainland use system is present in oceanic islands classified in continental land use concept and island land use concept. Continental land uses static concept determined by the common vision of urban areas developed in continental lands, applied and imposed in islands territories. These areas include the urban, agriculture, protected and road zones producing the fragmentation of the island ecosystem.

Additionally, the island land movement concept integrates the understanding of cycles, flows of energy and resources present into the oceanic island such as the primary essential zones for determining the land use. A living ecology implies components such sun, rain, wind, and soil. These two concepts continental land and island land present a vital necessity of integration land use which could be delimited by the watershed as a spatial boundary system for oceanic islands (Figure 4).

\subsection{Related to Natural Spaces}

\section{Hierarchical Space Patterns}

Human and ecological patterns determine the spatial hierarchy, influenced by the land use as a spatial element within the landscape which establish the whole local ecosystem boundaries characteristics. Normally natural boundaries do not correlate with the administrative boundaries. According to (Forman, 1995) boundaries determined by natural processes, such as drainage basins and bioregions, are theoretically optimum, which it is not wise to wait for society redraw

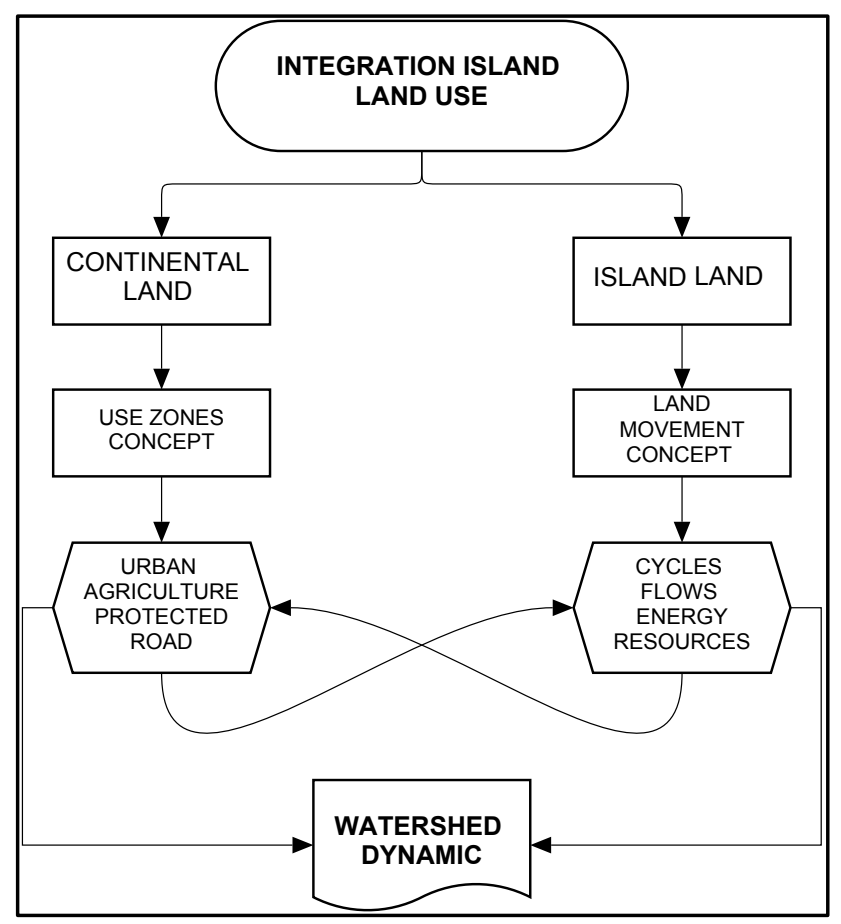

Figure 4. Integration Island Land Use. 
the land. As has been noted, establishing a hierarchy land system order in landscape planning generates a balance and an integration between natural and human systems.

"Human activities almost always interact with the natural process to produce the actual patterns, movements, and changes observed" (Forman, 1995). In this case, landscapes types variables such as native vegetation, agriculture, and the built area could define a matrix with specific boundaries, size, and spatial arrangement (Figure 5). Spatial patterns represented by natural horizontal processes are wind, water and animal movement which produce several irregular patterns in scale and shape. On the other hand, humans produce different patterns modeling the landscape based on different motivations in contrast with natural patterns. Human patterns create shapes most of the time based on Euclidian geometry.

"Over the past two decades, the patch-corridor-matrix model has emerged as the prime model for understanding natural and human patterns on land" (Forman, 2014). Their attributes and interpretation about structure, function area spatial patterns are variables necessary for determining the changes in the landscape. Patches determined by type, size, and shape are present in direct connection with corridors determined by size and longitude integrated inside a matrix. These three elements have boundaries with different characteristics from the interior of the patch and matrix (Figure 6).

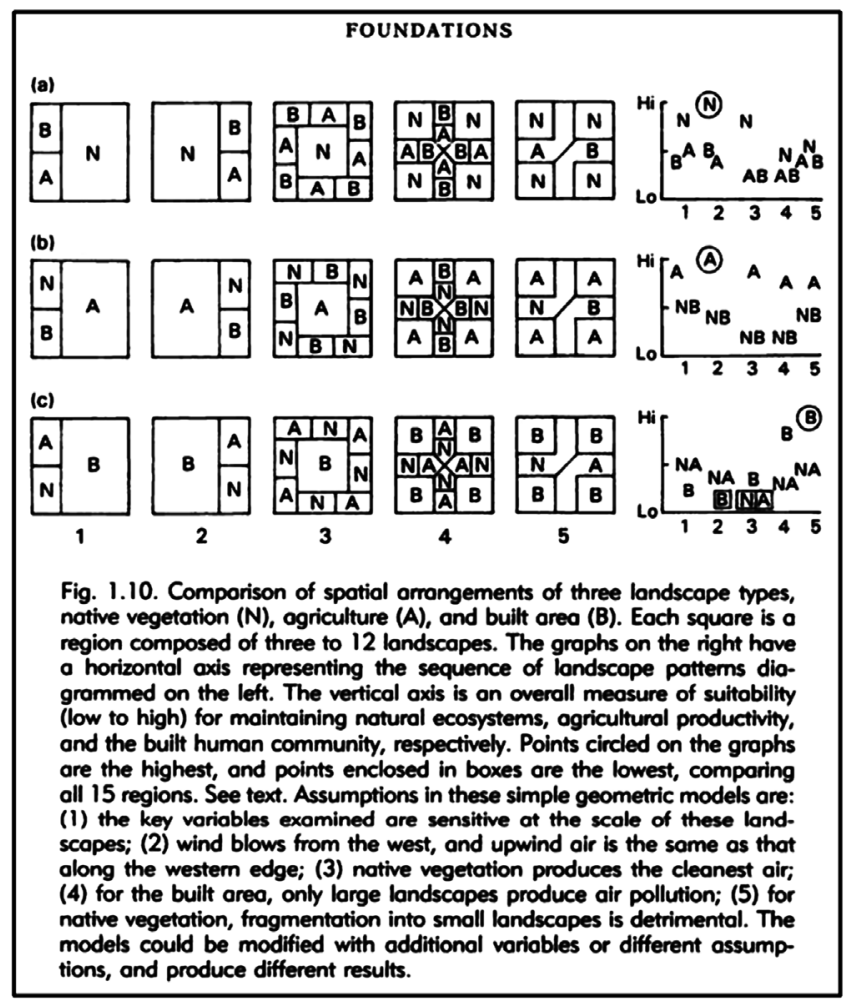

Figure 5. Foundations native, agriculture and built matrix from Forman (1995). (a) Native-vegetation matrix; (b) Agriculture matrix; (c) Built matrix. 


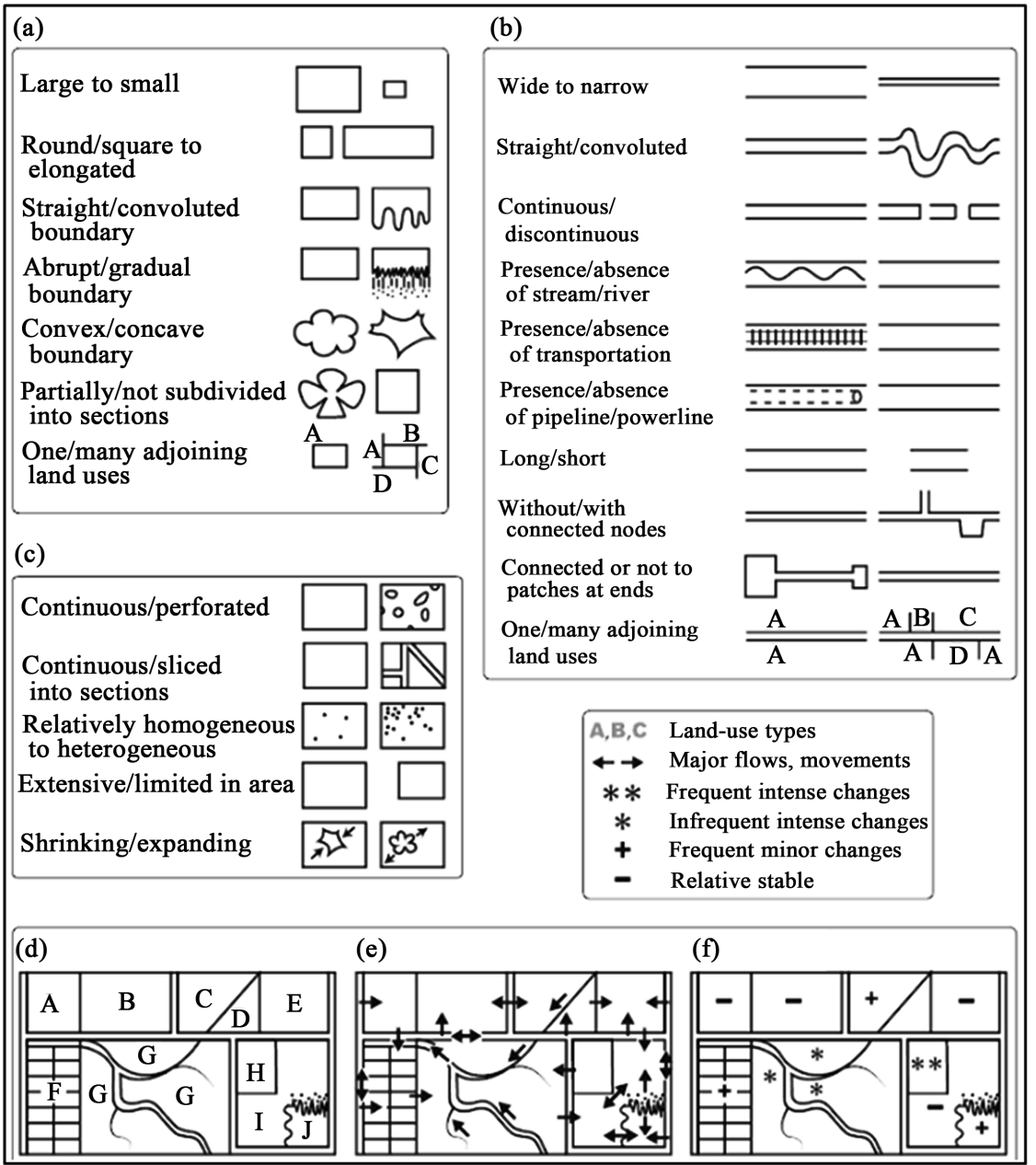

Figure 6. Patch-corridor-matrix and structure-function change characteristic of a land mosaics from Forman (2014). (a) Patch; (b) Corridor; (c) Matrix; (d) Structure; (e) Function; (f) Change.

These theories create several interactions between the spatial concept of patch, corridor, and matrix. Under those circumstances, manage the spatial hierarchy of the matrix it is possible by the creation of several interactions between the components such paths and corridors into the landscape matrix structure (Figure 7).

\subsection{Related to Landscape}

\subsubsection{Importance of Movement Structure}

Ecological process determined by the distribution of resources in patches in the whole landscape, focus the importance of the movement as a component of landscape structure. Animals move among the resources patches according to their needs and each patch supplement their resources with those in additional patches, the movement from sources and the individual move between patches according to the permeability of the boundaries patches. According to (Taylor et al., 1993) (Figure 8) the distance and the ability to get contiguous patches are 


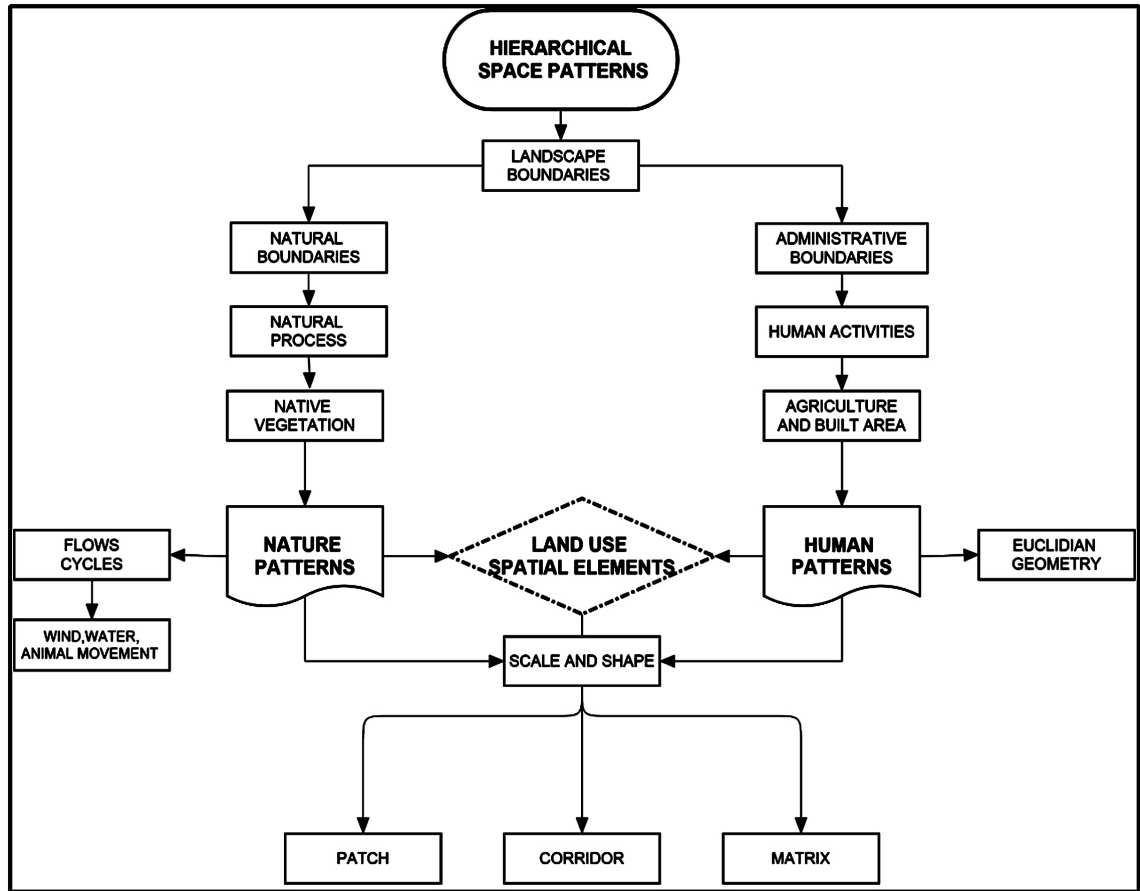

Figure 7. Hierarchical space patterns.

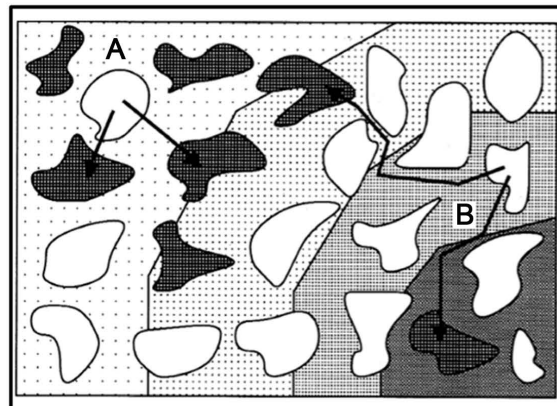

Fig. 1. Landscape complementation. Landscape connectivity underlies a mosaic of patches. Light and dark patches contain different resources required by the animal. Darker background areas have higher connectivity. Animals in area B can access patches more easily (arrows) and so will be able to complement their resource needs. Contrast with Fig. 1 of Dunning et al. (1992) where landscape connectivity is assumed to be homogenous over the landscape.

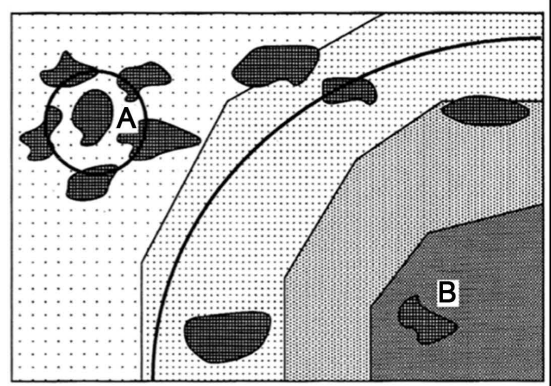

Fig. 2. Landscape supplementation. Landscape connectivity underlies a mosaic of patches. Darker background areas have higher connectivity. Animals in area B can access other patches more easily than animals in area A (areas within circle) and so Dunning al (1992) where landscape connectivity is assumed Dur be smaller.

Figure 8. Landscape complementation and landscape supplementation from Taylor et al. (1993).

requirements for landscape connectivity is the degree to which the landscape facilitates or impedes movement among resource patches.

Mathematical models could represent the dynamic of the animals, so the different population's behavior depends on the landscape connectivity. "The degree to which the landscape facilitates or impedes movement among resource patches, determine the landscape connectivity" (Taylor et al., 1993). This connectivity is just not a physical distance between patches because incorporate movement as a fundamental pattern determines population viability as a resource of distribution and conservation. 


\subsubsection{Structural and Functional Connectivity}

Landscape connectivity is the physical structure description about habitat and land use developed in a spatial heterogeneity. Understand the landscape connectivity as a component of biodiversity and a dynamic property. "Landscape connectivity results from the interaction between a behavioral process (movement) and the physical structure of the landscape" (Taylor et al., 2006). Two different kinds of connectivity are present in the landscape the structural and functional connectivity. Structural connectivity describes the "measured of the landscape structure, independent from the species approach are developing in different ways such as the physical relationships by the landscape metrics, spatial analysis" (Forman, 1995).

On the other hand, functional connectivity considers behavioral responses of the organism (Forman, 1995; Tischendorf \& Fahrig, 2000), when anomalies appear in the structural connectivity. Structurally connected not always means functionally connected, all depends on the habitats and species movements. The evaluation of landscape connectivity requires species approach, several new methods for analyzing movement data is becoming necessary for a better detail understanding about the species interactions with the landscape.

Roads and waterways alter the heterogeneity of the matrix structure present in the landscape; cultivated fields may create asymmetries in the connectivity of populations. "Landscape connectivity is important because it influences access to resources and colonization of empty habitat. However, population persistence at the landscape scale ultimately depends on the balance between reproduction and mortality" (Taylor et al., 2006). Human impacts in the matrix can affect the landscape connectivity reducing the connectivity by roads effects or increasing the mortality of the species. Landscape connectivity needs to be understanding as a component influenced for several factors affecting positive or negative the species biodiversity.

\subsubsection{Ecological Networks Applied in Urban Landscapes}

Several ecological theories about landscape morphology, ecological integrity, systems theories, and hierarchy theory came based on the necessity of biological conservation. Nevertheless, there is the necessity to clarify and develop methods and theories about the relation between ecological networks applied to a different urban context. The ecological perspective based on the multiuse of the ecosystems, which create a planning concept of ecological networks.

The network purpose by (Cook, 2002) is creating an integrated system determined by three principal components: hydrology, habitat and cultural opportunities. Hydrology considers as the dominant system is examined initially for its quality of establishing connections. Also, the importance of assessing hydrological elements is relevant to determining the hydrologic functions as drainage corridors, water recharge areas, flood containment. Hydrology structure hierarchy system can be the principal tool for re-establish connections in areas affected by urban development. 
At the same time, the system has to be environmentally oriented for human activity combining the cultural elements with significant ecological value. "Lynch (1960) provides a basic theoretical structure for understanding physical characteristics of a city that have meaning to inhabitants. The five elements: landmarks, nodes, paths, edges, and districts can be reinterpreted for inclusion in ecological network planning" (Cook, 2000). The measured of these indicators can give the right tools data for determining the specific patch content, corridor content and network structure analysis. These component functions determine levels of priority according to the specific characteristics of each case study.

\subsubsection{Landscape Connectivity}

The integrity of the landscape is the result of the interaction between the different ecosystems that integrate it. Landscape management demand an ecosystem approach involves social development and environmental protection. Land fragmentation, the decline in biodiversity, changing land use, habitat loss exacerbated by climate change putting pressure on ecosystem services. If we increased the landscape connectivity can produce a direct increase of the supply of ecosystem services "The landscape approach considers not only ecological but also socio-economic and aesthetic functions of corridors and buffer zones" (Troumbis et al., 1995). Effective management of ecosystems has to include natural resources conservation about social welfare.

Landscape connectivity shows the dynamic property of the movement in direct relation to the physical structure. Two types of landscape connectivity the structural and functional (Tischendorf \& Fahrig, 2000) determined by the spatial analysis and behavioral responses. Connectivity determines the matrix structure affected by alterations of human impacts (Taylor et al., 1993) and natural or human activities disturbances (Forman \& Godron 1981; Forman, 2014) (Figure 9). Additionally, the habitat characteristics which create the distribution and conservation of species. Habitat and disturbances show a spatial heterogeneity giving a new spatial concept for an island landscape network system between nature and urban spaces (Figure 10).

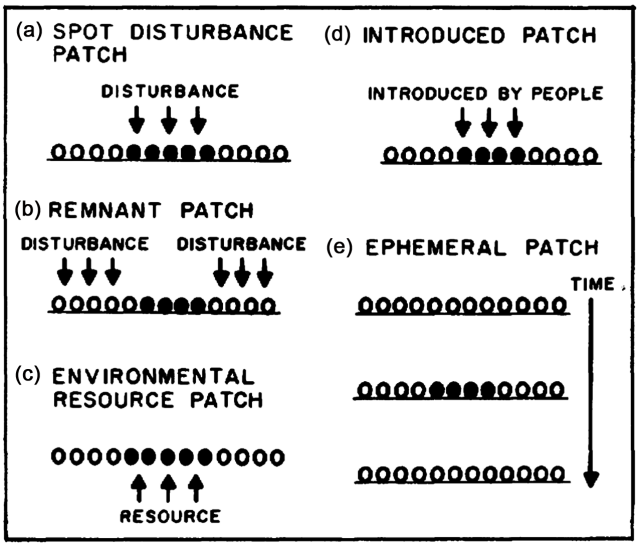

Figure 9. Patch origins. From Forman and Godron (1981). 


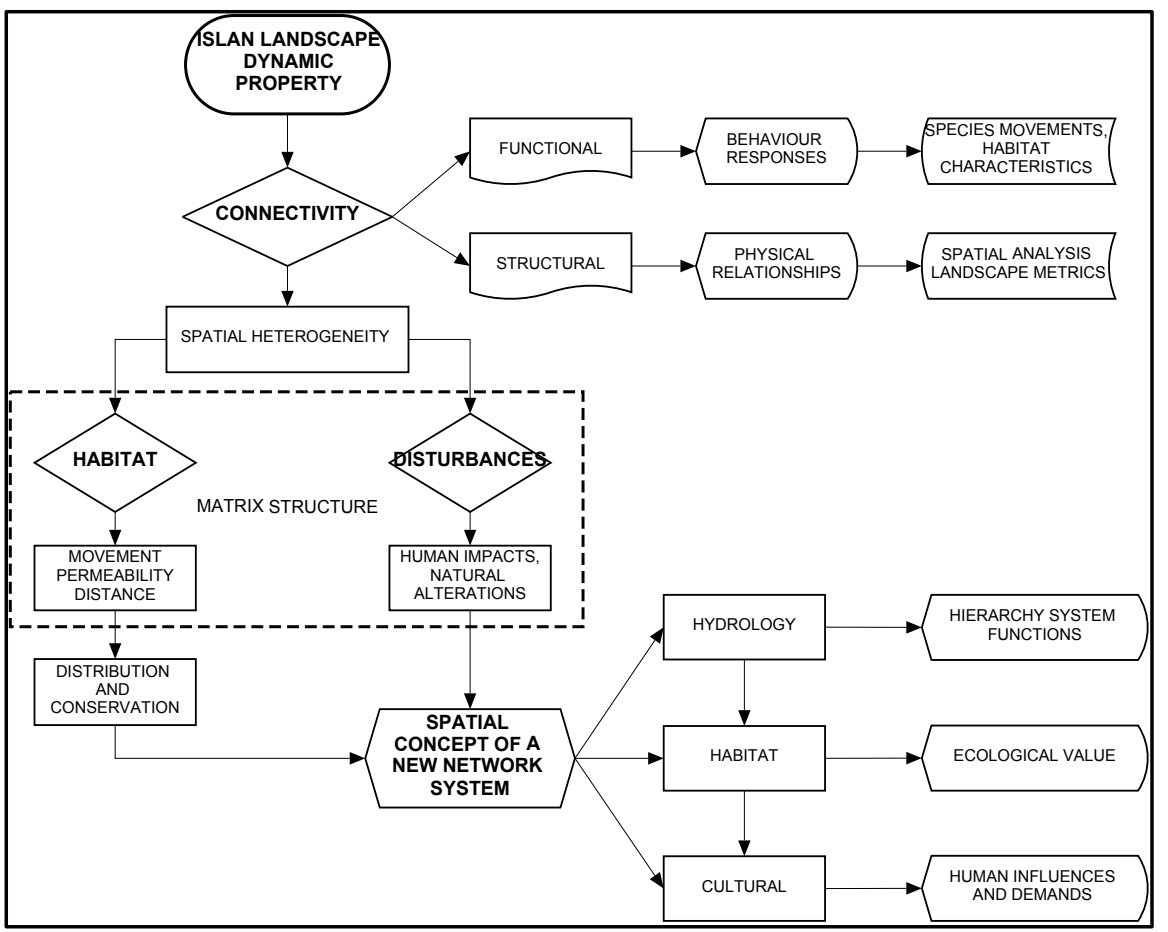

Figure 10. Island landscape dynamic property.

\section{Spatial Elements in Oceanic Island Systems with the Case Study of Santa Cruz Island Galapagos}

\subsection{Elements}

\subsubsection{Zones}

\section{1) Urban Habitat}

Islands are a living laboratory of model systems to understanding the human cultural evolution in direct relation with ecosystems. Complex dynamics involves interactions between environmental and sociocultural factor inside the urban zones of the islands. Population growth in island cities contributes to urbanization in a constant process of reciprocal socio-ecosystems relations. The impact of human land use on the native vegetation, forest cover and low land and higher mountains create a critical vulnerability of marine environments.

The urban settlements within the islands have been developed with the spatial definition of nature "there" and the city "here", creating great conflicts of valuation of the urban territory without concern for the ecosystem functioning. As a result, urban island planning created landscape alterations and soil degradation. Despite the clear delimitation established between zones for urban expansion and protected areas, there has been an urban growth without a proper model adapted to the ecological characteristics of the islands, creating the significant problem of landscape fragmentation. Additionally, the island size and geologic age have some effect avoiding some elasticity concerning the human intrusion. In the cases considered here, however, the importance in determining whether urban island zones could be worked in relative connectivity and respect with the 
environment.

Populated areas are the zones where is located the origin of the most important ecological problems. They coexist harmoniously between populated areas and protected areas in a heritage natural island such as Galapagos Archipelago ${ }^{3}$ (Figure 11) where population demand development pressure within a small territory has created a not true dialogue of relations between ecological and social systems present on the island. Nevertheless, connection allows urban-dwellers to learn first-hand about natural process and provides opportunities for value them with the approach to integrate the population understanding the benefits of the ecosystems and keep the natural heritage place.

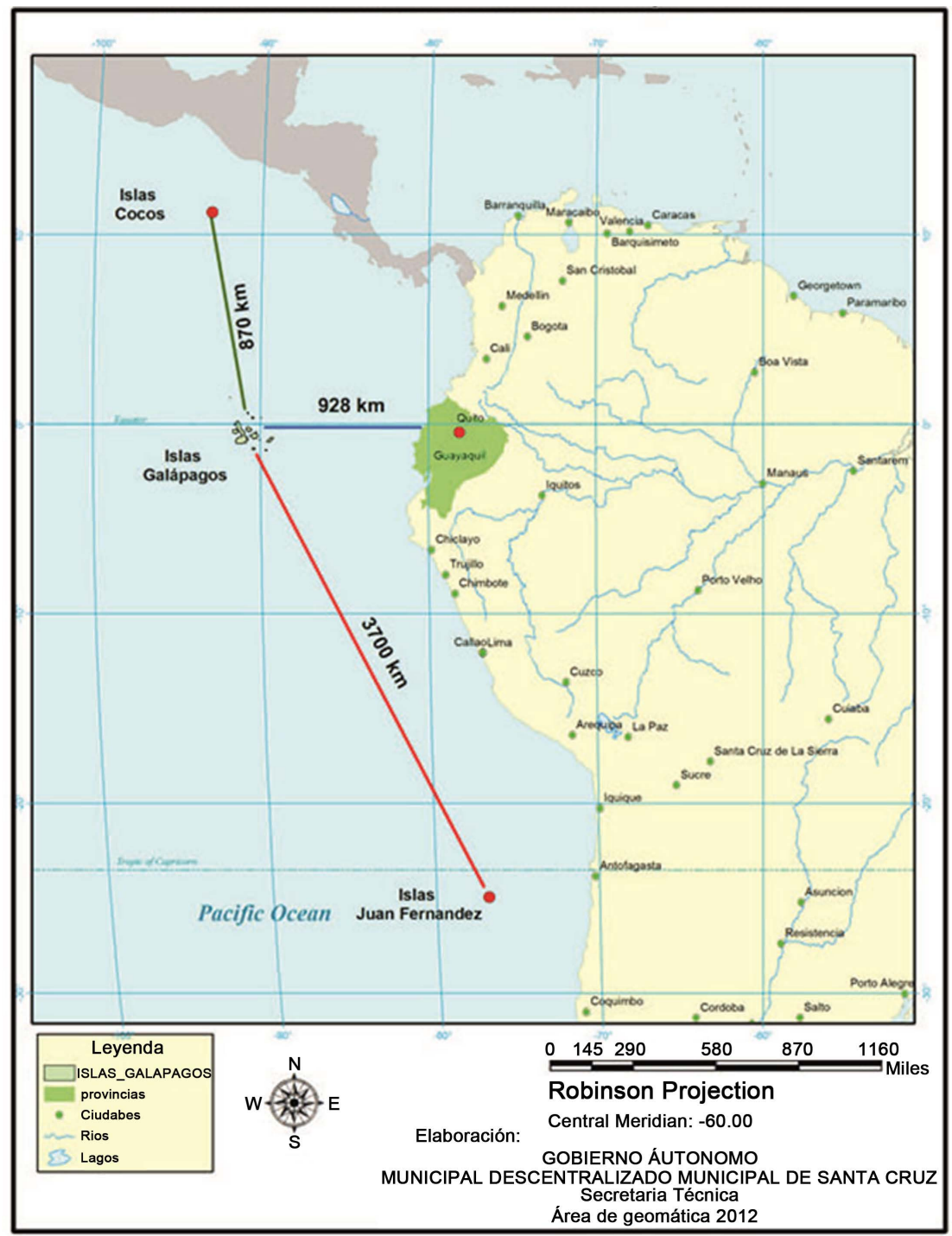

Figure 11. Galapagos Archipelago Location. From Plan de Desarrollo y Ordenamiento Territorial 2012-2027 (2012).

${ }^{3}$ Galapagos Islands are part of Ecuador country territory. Galapagos Islands were declared National Park in 1959, Natural World Heritage Site by Unesco in 1978, although Marine Reserve in 1998, famous for own endemic and native species which contributed to the theories of Charles Darwin. 


\section{2) Agriculture}

Food security is a particularly important factor in the island economy. Islands have the big necessity to cover the population and tourism demand for food. Most of the time, the total production is not enough, and the necessity of imports came as the principal solution for this issue. "The amount of available arable land per person is commonly small, and many islanders are coming to depend on imported foodstuffs" (Nunn et al., 1999). However, import means major issues as price and nutritional standpoints. The importance of agricultural came less when different activities such as tourism construction and public works became the principal income for the population. "However, several obstacles that need to be addressed to enable sustainable agriculture to succeed. On an island level, food production is difficult due to unreliable water resources, ineffective irrigation systems, rocky soils, and the lack of available labour" (Khatun, 2018). Different objectives for developing the agriculture in islands is becoming necessary for the equilibrium of the ecosystems. Tools such as organic agriculture practices are giving new opportunities to farmers. The purpose of island agriculture system is ensuring the environmental integrity not using chemical inputs and helping in the control of invasive alien species.

All things considered before affect the Santa Cruz Island ${ }^{4}$ (Figure 12), where the colonization of the island began with agricultural expansion. The unique native ecosystems began to transform, especially in the humid highlands of the inhabited islands, where colonists reared livestock and grew crops on the fertile volcanic soil. This fact has been a big problem because as (González et al., 2008) said: "Agriculture and cattle ranching are also critical for conservation and sustainability because these activities occupy the most vulnerable ecosystems of the humid highlands. These areas are essential for alien species control and the maintenance of the natural hydrological regime." Since tourism is the most critical driver of the economy, has caused farmers to abandon their lands and work on tourism-related activities.

3) Forestry and vegetation cover

Islands content an extent forests cover. "In spite of the relatively small area of forest cover in global terms, some tropical and sub-tropical islands have significant forest cover and are characterized by comparatively short distances between upland and coastal forest areas" (Wong et al., 2005). These are important regulators of cycles of fresh water, contribute with the food security, protect the cost from erosion producing an important impact on the coast and marine systems. "The conversion of forested areas into agriculture or construction areas may jeopardize the sustainability of island systems, considering the crucial role of forests and regulators of hydrological cycles." (Calado et al., 2014). Forest is crucial for buffer protection from tropical storms, hurricanes, tsunamis.

${ }^{4}$ Santa Cruz Island is part of the Galapagos Archipelago with a total area $(983.41) \mathrm{km}^{2}$. It is the island with the highest population $61.3 \%$ of the entire province, additionally $95 \%$ of the island territory is protected under the category of National Park. 


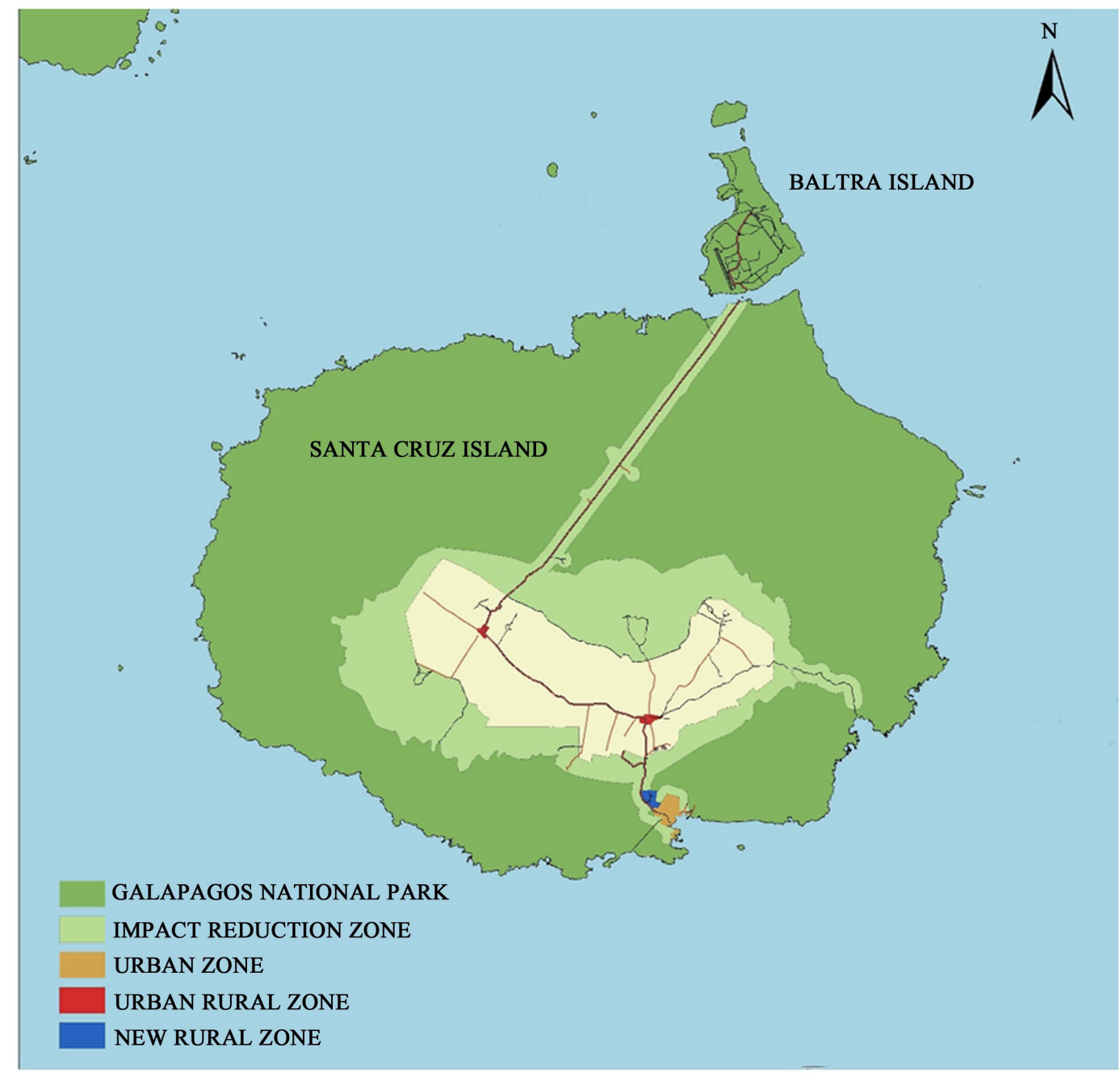

Figure 12. Santa Cruz Island. From Plan de desarrollo y ordenamiento territorial 2012-2027 (2012).

In the case of Santa Cruz Island, the characteristics of the land based on the study of the rural area of the island show that "From the coast up to 50 ma.s.l., conditions are dry, spiny shrubs and cactuses dominate. Between $50 \mathrm{~m}$ and 200 $\mathrm{m}$ a.s.l., vegetation progressively evolves to forests and soils are deeper. The humid zone extends from 200 to $450 \mathrm{~m}$ a.s.l. Moreover, was originally covered by the endemic Scalesia tree" (Hamann, 1979). From the coastal area to Bellavista it is considered a gentle slope, and from Bellavista to Cerro Crocker, an average slope is maintained. There is a direct relationship between land use and invasive species, the more intensified the use, invasive species decrease and vice versa. The abandonment land produces the invasion species propagation to all the territory including the National Park.

\section{4) Coastal}

The coastal zone integrates the terrestrial and marine ecosystems where the sun, rain, wind, soil have a direct influence in the dynamic of the island and sea activity. "Coastal resources on oceanic islands are interwoven into the fabric of 
the terrestrial, social and economic lives of their inhabitants. Common to most island coastal areas are rich marine lore that has been built up and survived for centuries, even millennia while being modified to suit changing customs, traditions and the socio-economic aspirations of people" (Nunn et al., 1999). Coastal zones in small islands represent the habitat space for the majority of the population where the essential equipment and services are present. Ports are present into the coastal zones, being the main important point of the link between island and others islands near or the mainland. It is an essential link for trade, transportation, and communication for local people and tourists.

The main environmental impacts influence the coastal zones, affecting the socio-economic activities. "The coastal vulnerability of island systems (particularly oceanic islands) results of the exposure of their extensive coastal areas to natural phenomena and dynamics, together with the inadequate infrastructures' development in the coastal zone, which may lead to serious problems of coastal erosion" (Calado et al., 2014). In the case of the Galapagos Islands, coastal areas are considered protected zones, with a level of controlled tourism, according to the marine reserve zoning. Although the population increase of the Santa Cruz Island accelerated under an inefficient regulation has generated that the area of the port has undergone overutilization causing problems of water pollution besides affectations to the biodiversity of the area. Finally, coastal zones are essential in the determination of human activities and effects on natural ecosystems. Prevent human impacts, and natural disturbances are crucial for the sustainability of coastal and marine ecosystems.

\section{5) Protected Areas}

Protected areas focus on the capacity of ecosystems to maintain ecosystem services and human well-being into the territorial matrix or landscape dimension. Protected areas are vital for the conservation of natural ecosystems and cultural heritage. At the same time, involves creating links between social development and nature conservation. The comparative advantage of analyzing the systemic relations and process that determine the links between social and ecological systems such as example is Galapagos Islands where protected areas comprise the territorial majority of the archipelago. This protected area gives an ecological limit within an eco-region. It understood that ecosystems if maintained a good level of ecological integrity, they constitute a true natural heritage because their ecological functions generate essential benefits to the well-being of society (DPNG, 2014).

Create socio-economics opportunities with the respect of the natural areas implies protection and planning of protected areas. "To protect the natural values while ensuring opportunities for socio-economic development can be even more complex in island systems, where space is extremely limited, and natural resources cannot be separated from the human activities" (Calado et al., 2014). The planning of protected areas must work into the dynamic of the systems present in the islands territories. 


\subsubsection{Paths (Dynamic Components)}

\section{1) Roads and Lanes}

Linear and non-linear habitat elements of the landscape are used to increase the ability of an organism to move according to the nature of the corridors or create recreational routes to linkage biodiversity. The corridor could be natural or artificial human managed connections. "The dynamic shaping of the movement line will give it identity and will produce a continuous experience over time" (Lynch, 1960). Patch movements should contribute with connectivity just not inter-patch but at the same time understanding extra-patch connections.

The soil sealing affects whole ecosystems, and manage this problem inside island territories where space is limited, but people demand services is a conflictive issue to resolve. Inside of urban environment, the potential lines of movement should have to be analyzed by segments of importance to create characteristics spatial quality for improving connectivity. The soil sealing effect on road and lanes marks the necessity of control manages about the surfaces applied on roads near to valuable ecosystems. This issue often occurs in island territories where the limited space creates close direct relationships between protected areas and urban zones. In the case of Santa Cruz Island, the main road, Baltra road, unify all the zones inside the complex systemic space of the island. For this reason, road and lanes should respond just not to the flows of people, also the ecological flows and establish alternative mobility such as the implementation of road and lanes with ecosystems-friendly soil covers.

\section{2) Streams}

"Stream encompasses surface and groundwater fluxes that respond to geological, geomorphological, hydrological and biotic controls" (Connelly, 2008). According to this idea, the focus is to redesign the broken land use system back into a resource of living ecology sustenance to generate wealth and feed life. "The development of streams limits the ability for watersheds to attract, absorb, filter, and distribute freshwater as it flows from the ocean to the mountain and back again" (Connelly, 2008). Urban and agricultural single-use areas put enormous pressure on the streams and force physical separations between natural resources. The streams are important channelization of water for support the biodiversity from the whole territory from uplands to ocean. As a result, the decreasing of the value of the stream create broken hydrology.

"Santa Cruz Island has no permanent rivers, only sporadic runoff during the winter or strong garúa" (d'Ozouville, 2008). Susceptibility to flood is a big area which covers the lower middle part of the rural area. This component has biophysical importance because it contains areas of swamps, ponds, and wetlands around the farmlands, the importance of recognizing and restore them are crucial for the protection and maintenance the biological process of different endemic and native species for the island. Due to the characteristics of the soil of the island where cracks and fractures predominate, groundwater or aquifers is the most abundant water resource on the island. The location and characteriza- 
tion of these several components inside the flooding zone would generate a linkage in the term of resilience in the case of inundation risk for the urban and rural zones.

\section{3) Corridors}

Corridors determined as a linear element present in the landscape have different characteristics in width and function. "These corridors provide habitat and breeding sites for species requiring the surrounding matrix environment for protection or feeding" (Forman \& Godron, 1981). Corridor also is defined such a "movement conduit with differences in width and function according to human disturbances influence" (Forman \& Godron, 1981), they include functions of habitat, conduit, filter, source, and sink (Forman, 1995). Additionally, are elements for connection to primary source areas, link various elements, mountains, and other landforms; the function of linear regarding connectivity such as "canals, road rights-of-way, utility corridors, and other elements can provide secondary links if managed sympathetically to habitat values" (Cook, 2000). Corridors area connectivity components promoting movement among habitat patches (Tischendorf \& Fahrig, 2000), essentially devices to maintain or restore a degree of coherence in fragmented ecosystems (Graham \& Kalemani, 2006). Finally, multiple intends aims such as conduit, habitat, filter, barrier, source, sink (Harrison, 2016) pressure reducing valves that connect organs of equilibrium in island scale (Mejías, 2018).

In the case of Galapagos Islands maintain the ecological systems and biodiversity, mainly the native and the endemic, allowing the continuation of the evolutionary processes of those systems, example the biological corridors that may consider as attractive tourist potential (GADMSC, 2015). These biological corridors could be a potential link between important biodiversity and vegetation core areas, necessary to be implemented for conservation and restoration in the islands.

\subsubsection{Boundary (Interaction Components)}

\section{1) Biosphere Reserve}

The biosphere reserve is the fundamental concept of a buffer zone for protected areas introduced by (UNESCO, 1974). According to concentric zoning, the design contains the core area as the inner ring represents by the most important biologically areas. The buffer zone is the second ring where control of resources is applied. Transition zone is the outer ring surrounding by human settlements, where cultural activities are permitted. "Biosphere reserves are areas encompassing valuable ecosystems and social communities that wish to combine the conservation of ecosystems with their sustainable use" (Fischer-Kowalski et al., 2011). The biosphere concept establishes the purpose of restricting and control economic activities to create adequate zones of protection.

UNESCO declared the Galapagos Islands as Biosphere Reserve in 1984. The zoning of the biosphere reserves determines three principal zones: the core area, 
buffer zone, and transition zone. In the case of the Galapagos Islands, it is necessary to adopt this concept in an inverted way. Since the gradient of concentric rings are determined peculiarly because the urban areas are the internal or core zones surrounded by the transition zone where the large matrix becomes the protected areas of the Galapagos National Park.

\section{2) Watershed Edge}

Watershed modification on islands has a negative impact on water resources regarding water quality and quantity as well as flow regime. Despite limited coverage on some islands, forested watersheds are critical regulators of island hydrology. "Without adequate freshwater resources, small islands depend on desalinated or imported water. Island water supply is often threatened by pollution, mainly from poorly treated sewage" (Wong et al., 2005).

"Boundaries established by the natural process as drainage basins and bioregions" (Forman, 1995) shows the importance of manage volume resources in islands as cycles of observation and interaction for design and establish the economy of islands in total ecology way concept. In the case of Santa Cruz Island, the definition of watershed boundaries and their associated drainage network at island scale and sub-watershed scale essential framework through which freshwater management could be addressed (d'Ozouville et al., 2008). Pelican Bay Watershed (Figure 13) boundaries have a direct relationship with the road access, farmlands, and the Galapagos National Park. For this reason, consider

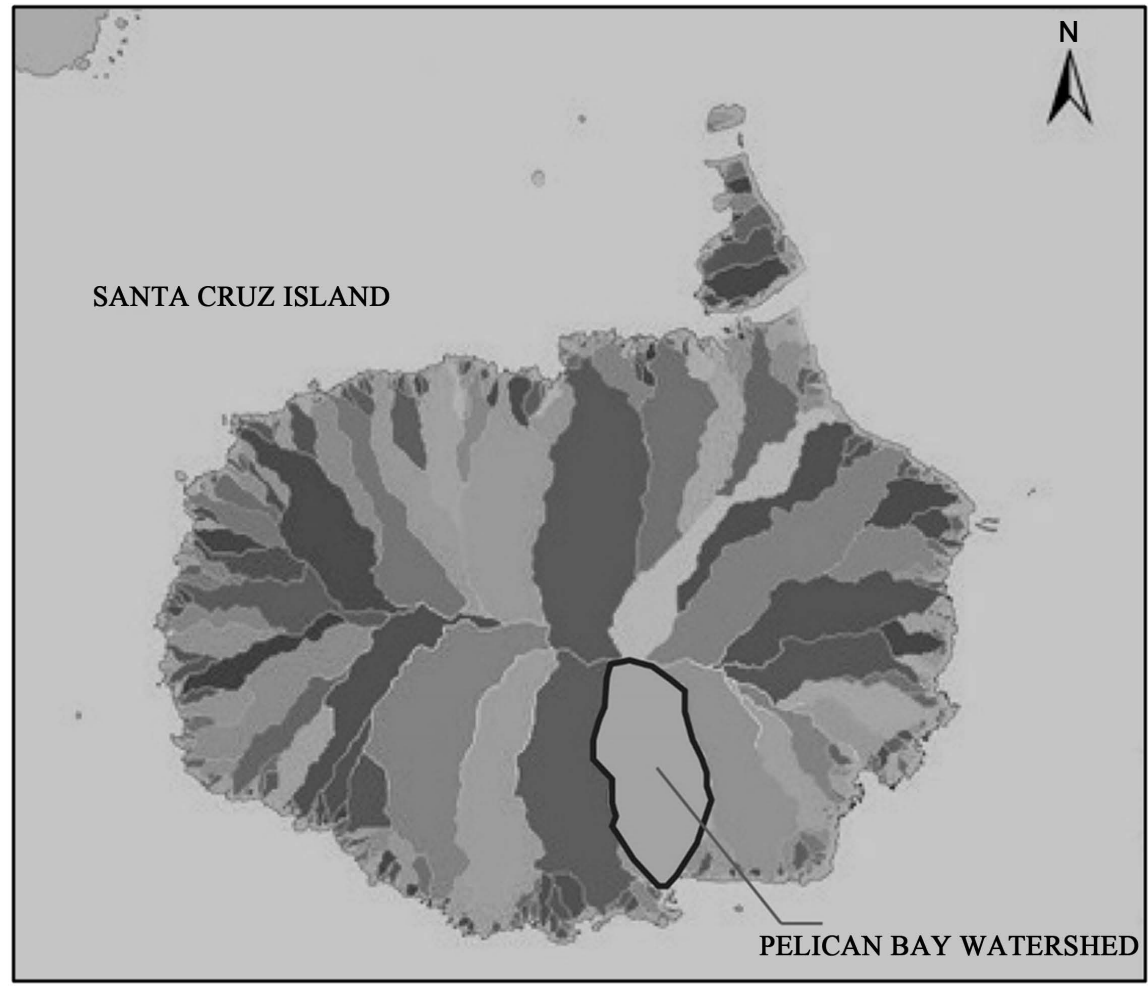

Figure 13. Pelican bay watershed location in the area of Santa Cruz island, Galapagos. From Plan de Desarrollo y Ordenamiento territorial 2012-2027 (2012). 
water system such hydrology structure hierarchy system and significant natural areas (Cook, 2000), provide the vision of watersheds often set boundaries of urban ecosystems. "Watershed ecology is essential knowledge for watershed managers because it teaches us that watersheds have structural and functional characteristics that can influence how human and natural communities coexist within them" (O'Keefe et al., 1996).

\section{3) Urban Edge}

Several definitions show the buffer ideas about its influence for landscape context. One of them is the concept of patch shape (Forman \& Godron, 1981). The separation of incompatible land uses, delineating property boundaries for changes in use or other cultural phenomena (Cook, 2000), transitional area by compatible land uses which protect the network from potentially damaging external influences (Graham \& Kalemani, 2006). There are necessary transitional areas situated between habitat and the matrix to reduce the impacts (Harrison, 2016). As a result, the buffer function allows a range of sustainable human activities with the high protective value of absorbing the pressures from outside effects.

In the case of Santa Cruz Island, the urban expansion creates urban edges directly bordering the area of the National Park. This situation creates specific issues of habitability and accessibility effect in this area, where is a necessary control on the permeability by specific segments, according to the edge condition. "The area of countryside surrounding urban areas, it must have a specific management plan for each of these cities, which are established guidelines on the one hand, to guide an ordering territorial proper and on the other, minimize the direct impact on the protected natural area, especially of invasive alien species" (DPNG, 2014). The important aspects to emphasize conflict of the edge is noise pollution and light produced by the urban area adjacent to natural areas which can alter daily cycles of activity of the fauna near to the edges zones.

\section{4) Road Edge}

The importance of addressing interactions between roads, vehicles, and wildlife creating green bridges, amphibian tunnels, and lands conservation is necessary to improve landscape connectivity. "The scientifically based programs have produced a wide range of mitigation approaches. These include wildlife overpasses, which have been found to provide the best landscape connectivity for many species" (Forman et al., 2002). "Corridors that link various elements are often manifest as drainage corridors or linear parks that have inherent recreational value. Often they function as a boundary or edge that is discernible by area residents and can be an essential contributing factor in establishing a district or community identity" (Cook, 2000). The study of the road segments contains different spatial dimensions of intervention for road ecology projects such as bridges or underpass highway.

Despite the restrictions that exist in Galapagos Islands about motor vehicle entry, they have not been entirely practical due to failures in the control as well 
as urban expansion, which has increased the demand for motorized mobility covering their needs. "The increase in the fleet and the acceleration of the flows are phenomena which manifest themselves in all the scales of mobility in the archipelago" (Guyot-Téphany et al., 2013). For this reason, it is necessary to create buffer zones along the Baltra Road, which is the primary connection and the place of direct interactions between motorized and biodiversity, with the primary objective of delineating property boundaries in response to the human mobility disturbances.

\subsubsection{Nodes (Static Components)}

\section{1) Habitat Biodiversity}

The theoretical framework starts with the development of the theory of island biogeography (MacArthur \& Wilson, 1967) about the patch dynamics and equilibrium theory. Nodes are classified in several kinds determined according to the level of disturbance which includes a remanent patch, environmental resource patch, introduced patch and finally ephemeral patch caused by normal short-lived fluctuations in biotic and abiotic level (Forman \& Godron, 1981). Habitat fragmentation is a process which transforms the habitat into some patches of smaller total isolated areas with different characteristics from the original. Core reserves are explicitly managed for wildlife species diversity. The protective value of core areas in ecological suitability, providing appropriate habitat conditions is crucial.

Also, the habitat biodiversity nodes include the fauna and flora which in the case of Galapagos has vital importance for its native and endemic characteristics. "The need for food created the need of introduced plants and animals that eventually transformed in difficult to control pests and that displaced, and They even displace those endemic and native" (DPNG, 2014). Biological diversity is an important measure of ecological health and represents a useful standard. While this should be a goal in designing urban landscape networks" (Cook, 1991). In the specific case of Santa Cruz Island, habitat biodiversity classified in four principal categories: Native-endemic species, endangered species, critically endangered species, and vulnerable species. As a result, the recognition of these specific nodes of habitat biodiversity is crucial for the protection and restoration of the species.

\section{2) Urban Patches}

"Nodes as direct concentrations, which gain the importance from being the condensation of some use or physical character" (Lynch, 1960). "Urban patches are representatives in size and diversity of the natural ecosystem within an urban context, cultural opportunities with significant open spaces" (Cook, 2000). Relates to the size and shapes of patches and corridors into the matrix, where the approach is on the integrity of the network. "Urban matrix patches and corridors are most often relegated to be remnants" (Cook, 2000). As a result, use the existing urban elements and exploit their potential as concentrator elements of 
natural functions or human productivity spaces.

In Santa Cruz Island it is necessary the evaluation of the nodes of interconnection of populated centers and areas of tourist interest with the aim of the revaluation of the urban nodes and tourist areas (GADMSC, 2015). At the same time, the Public Space factor is an essential urban patch to be considered. The presence of public space in the urban zones of the island is scarce, and the few areas that exist cannot be cataloged as specific green areas. "This as a result of the soil characteristics where the lower part of the island the conditions are arid, spiny shrubs and cactuses dominate especially in the urban area of Puerto Ayora" (Alexandre et al., 2012).

According to (Cook, 2000) in an urban context, many areas may not be suitable as a primary habitat for some species requiring greater isolation. However, many species may rely on these areas for migration and as islands for refuge or forage. They may also be utilized as secondary habitats. Because both plants and animals disperse through these areas, they are important conduits for nutrient, energy and gene flow. As a result, generate public space with the same natural characteristics of protected areas, can be used as urban patches connected to generate the integrated systems for a socio-ecological balance.

\section{3) Intersection Human Roads and Animal Lanes}

Roads intersection into the island's territory became a significant impact on biodiversity conservation. The nodes imply urban and natural flux by comprises points of intersection between vehicles, pedestrians, and wildlife. Vehicles and pedestrians developed flows on the surface. On the other hand, animals produce flows in several dimensions on the surface up and down. As can be seen nodes intersections by human roads and animal's lanes needs a specific treatment by a physical mechanism for the dynamic of the islands.

Santa Cruz Island road infrastructure is present inside the all spatial zones which facilitates the flow of people on land between national park area, farmland areas and populated centers, producing intense human flows at all scales. This situation has produced several environmental problems includes the fauna affectation. "The proportion of birds dying from vehicular trauma likely overestimates the overall number of trauma deaths relative to other causes of mortality, due to biased sampling; dead birds are highly conspicuous on the Santa Cruz-Baltra road, and this is the major road in the entire archipelago" (Gottdenker et al., 2008). The road infrastructure is the backbone of the exchange of terrestrial flow for residents and tourists because it covers all the natural and human ecosystems areas present on the Island.

\subsection{Networks}

\subsubsection{Matrix Hierarchy}

The matrix utility refers to the area surrounding patch boundaries which are influenced by the significant human impact. Patches and corridors interrelationship are developed inside the urban matrix marked by the variables of density, 
circuitry, and connectivity. "Essentially there are three main ways of examining regional contextual factors, watershed dynamics, species diversity, and political management units." (Cook, 2000). Significant natural areas could determine the matrix landscape scale in oceanic island territories.

Establish a hierarchy land system according to natural boundaries create balance and integration between nature and human's patterns. "The matrix utility index is a measure that can be an essential tool in the urban planning process that can help preserve the integrity of important patches and corridors within the urban matrix" (Cook, 2000). For this reason, defined a matrix as the spatial model for the structural and functional connectivity, allow to restore the natural elements affected by the human impacts.

The Galapagos Archipelago is above all; a vast ecosystem is say, a functional unit of large dimensions, which it is structured hierarchically by components linked by a network of biophysical relationships. "The spatial expression of this functional unit of large size is what is known as eco-region" (DPNG, 2014). It is necessary to consider the islands such as a complex systemic space, where it is possible to understand the interdependent relationships between vegetation, water, soil, and human settlements.

\subsubsection{Social-Ecological Network}

Ecological networks objective is maintaining the integrity of environmental processes to reduce human activities on biodiversity conservation. "Indicators as production, biodiversity, soil, and water are determined by the assessment of ecological integrity" (Forman, 1995). Landscape patterns and landscape fluxes are necessary elements to analyze as part of ecosystem networks. "The landscape scale network becomes the main, and more stable, structure" (Cook, 2000). "The zoning system of urban planning and urban facilities could be systematized based on the urban ecological network" (Kyushik et al., 2011). According to these authors landscape approach gives the principal structure system for the urban and ecological facilities components links.

Socio-ecological system approach creates interactions in every landscape focusing on the social and ecological analysis together with the objective of conservation incorporating social process. To point out the importance of ecological and social relationships are present in several studies that highlight human and natural interactions for example: Determining urban systems as social, biological and physical complexes (Pickett et al., 1997), the ecological value in combination with cultural value as a network component (Cook, 2000), and the interaction of human and urban ecosystems (Grimm et al., 2000). "Urban ecological network can be defined as a physical linkage system designed to preserve ecologically sensitive areas and to connect those areas to urban areas" (Kyushik et al., 2011). Additionally, use the ecological perspective on urban ecological networks as a tool for re-establish the viability of ecosystems, as a part of a larger functioning system (Cook, 2000). For this reason, impulse the connectivity for both ecologi- 
cal and societal benefit broad aim of maintaining the integrity of environmental processes and adaptation to climate change.

It is necessary to consider the island as a complex systemic space, where it is possible to understand the interdependent relationships between vegetation, water, soil, and human settlements. In this case, Galapagos Islands is a clear example for social-ecological network system approach. We picked such a case study the specific area inside the Santa Cruz Island determined by the "Pelican Bay Watershed was chosen because it encompasses Galapagos National Park land, agricultural land, and the most densely populated area" (d'Ozouville et al., 2008). Pelican Bay Watershed has an area of $43 \mathrm{~km}^{2}$. It extends from the higher point of Island, Cerro Crocker, includes the villages of Bellavista and Puerto Ayora, and ends at its outlet to the sea point in Pelican Bay. The watershed delineation revealed that the most significant human development on Santa Cruz Island is concentrated on one watershed alone in direct relation with ecological and agricultural zones (Figure 14).

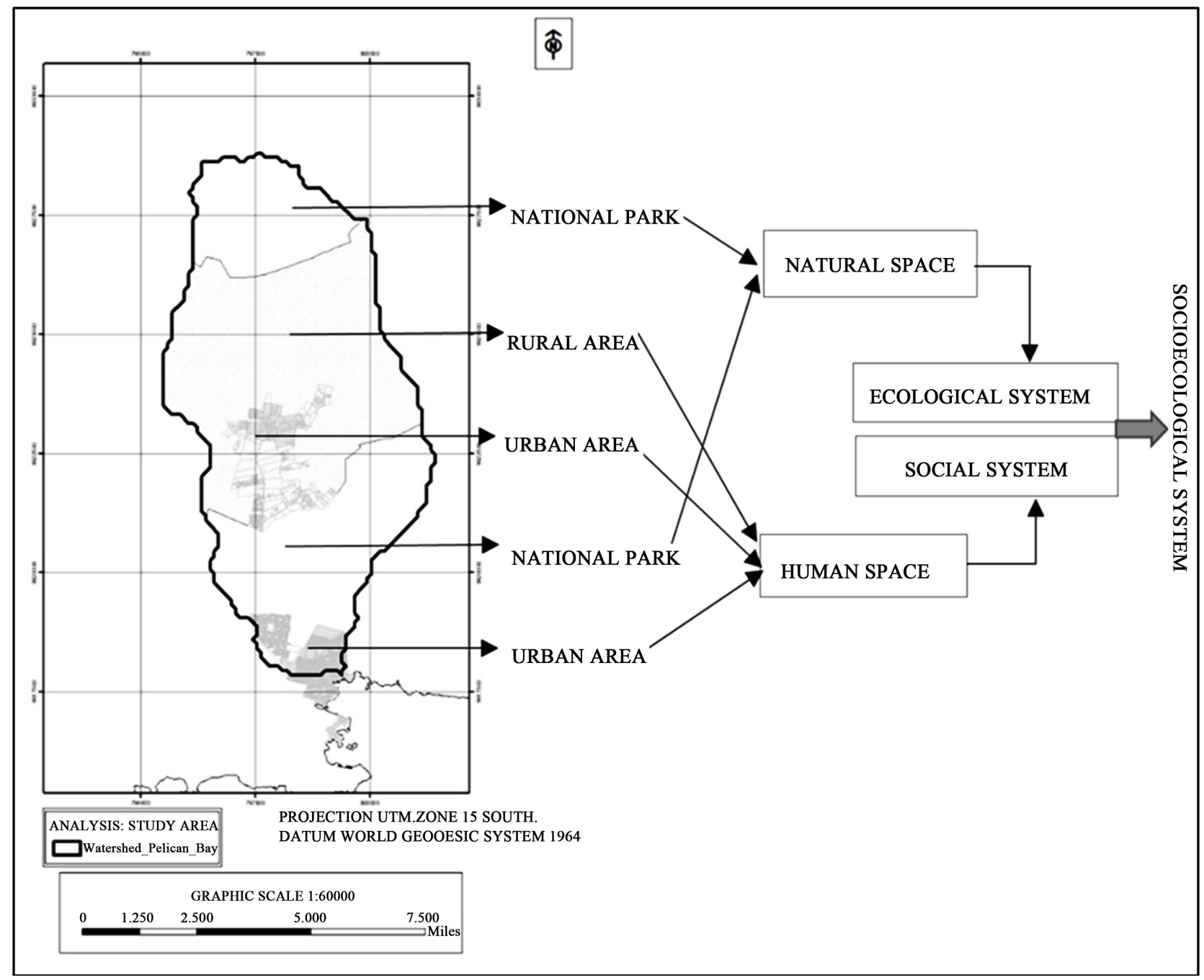

Figure 14. Pelican bay watershed (Socioecological system). 


\subsubsection{Road Networks}

Several analyses show about the road system and its influence on the landscape connectivity. Roads effects reduced the connectivity and increased the mortality of species (Taylor et al., 2006) creating networks with high human pressure such as road and railroads (Forman \& Godron, 1981). Studies that assume higher movement, but do not include higher mortality in the matrix, can lead to the erroneous conclusion that removal or fragmentation of habitat may enhance interactions among local populations at broad spatial scales (Tischendorf \& Fahrig, 2000). The studio of the influence, effects and potential connections around the road system give specific variables to manage the significant disturbance about the landscape fragmentation.

The road system influences the managing of the matrix. "The vital line of circulation can become the symbol of a fundamental urban function" (Lynch, 1960). Manipulate the behavioral responses of the species creating bridges or tunnels for the road system effect in their habitats could be a good strategy (Taylor et al., 2006; Forman et al., 2002). Manage the road networks for an ecological connection; it is necessary to understand their influence on the urban and natural landscape. "The paths, the network of habitual or potential lines of movement through the urban complex, are the most potent means by which the whole can be ordered" (Lynch, 1960).

The road network in the case of Santa Cruz Island is connected by the main road artery Baltra Avenue, which facilitates the flow of people on land from the Itabaca Canal, through the National Park area, agricultural areas, and population centers, for reach to the port. As a result, great human flows at all scales are present. All the people who arrived at the airport on Baltra Island have to use Baltra road, this route, approximately $40 \mathrm{~km}$ in length is the major road in the entire archipelago. The road infrastructure components identified in Santa Cruz Island are classified in the main road, secondary road, path, and cycle lane. These components conform the road network inside the island territory.

\subsubsection{Hydrology Network}

Maintain the water resources it is vital for all landscape because the water is the principal generator of life, the transport of nutrient, energy and gene flow. For the purpose of conservation to this vital element, several studios focus the importance of stream corridors (Forman \& Godron, 1981), dendritic networks (Forman, 2014), hydrology as drainage corridors, water recharge, providing habitat refuge (Cook, 2000) and stream encompasses surface and groundwater fluxes (Connelly, 2008). Under those circumstances, the protection and channelization of water resource is the primary objective and necessity for landscape connectivity and support the ecosystems in relations with human influence.

Recognize the local hydrology system in its multiple structures it is necessary for an appropriate urban ecological development. In the case of Santa Cruz Island "It is necessary to consider the freshwater ecosystem as a dynamic entity, where the quantity and type of rainfall play a major role in generating runoff and 
interlinking the individual small freshwater ecosystems" (d'Ozouville, 2008). The current situation is critical, and the local population relies on expensive desalination techniques (d'Ozouville, 2007). Freshwater is a limited resource on Santa Cruz island, under those circumstances, hydrology is a crucial component for island urbanism structuring network to ensuring the integrity of the systems.

Due to the characteristics of the soil of the island where cracks and fractures predominate, groundwater or aquifers is the most abundant water resource on the island. For this reason, in island territories, the flood control is always a high priority, and one of the essential factors understood as a cycle of attracting, absorbing, filtering and distributing freshwater. Finally, the flow of resources and energies between humans and nature marks the understanding of different ecosystems as an interrelated structural and functional network of the ecological, physical and social components inside the Island Network System (Figure 15).

\subsubsection{Island Network Systems Integration}

It requires a vision that integrates existing phenomena such, loss of biodiversity, land fragmentation, mobility, the need for access to environmental services, the

\section{SOCIOECOLOGICAL SYSTEM}

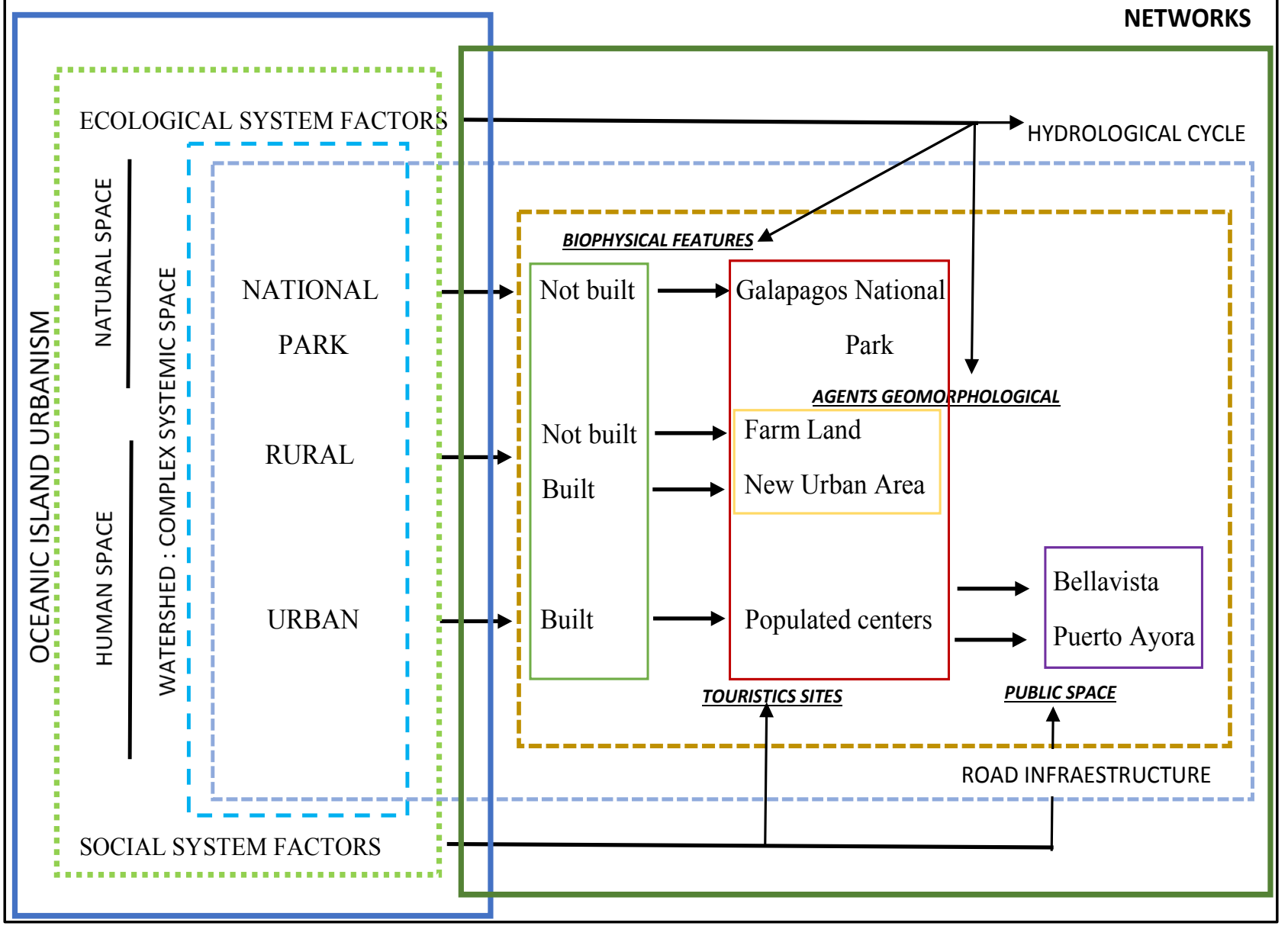

Figure 15. Santa Cruz island network system. 
impact of natural tourist areas and urban services, into the oceanic island complex Socioecosystem. The integration of the two main systems which determines the oceanic island Socioecosystem into the watershed boundaries. This landscape system strategy creates the spatial network elements with the approach of the Island Network System (Figure 16).

The static use zones concept from continental land influenced the territory development of oceanic islands. Dividing into three principal zones urban, agriculture and conservation. This land division is outside from a basic comprehension of which oceanic island territory means. Finally, the watershed system boundaries with the urban ecological network system determine a physical linkage system integrated by the social-ecological network, hydrology network, and road network (Figure 17).

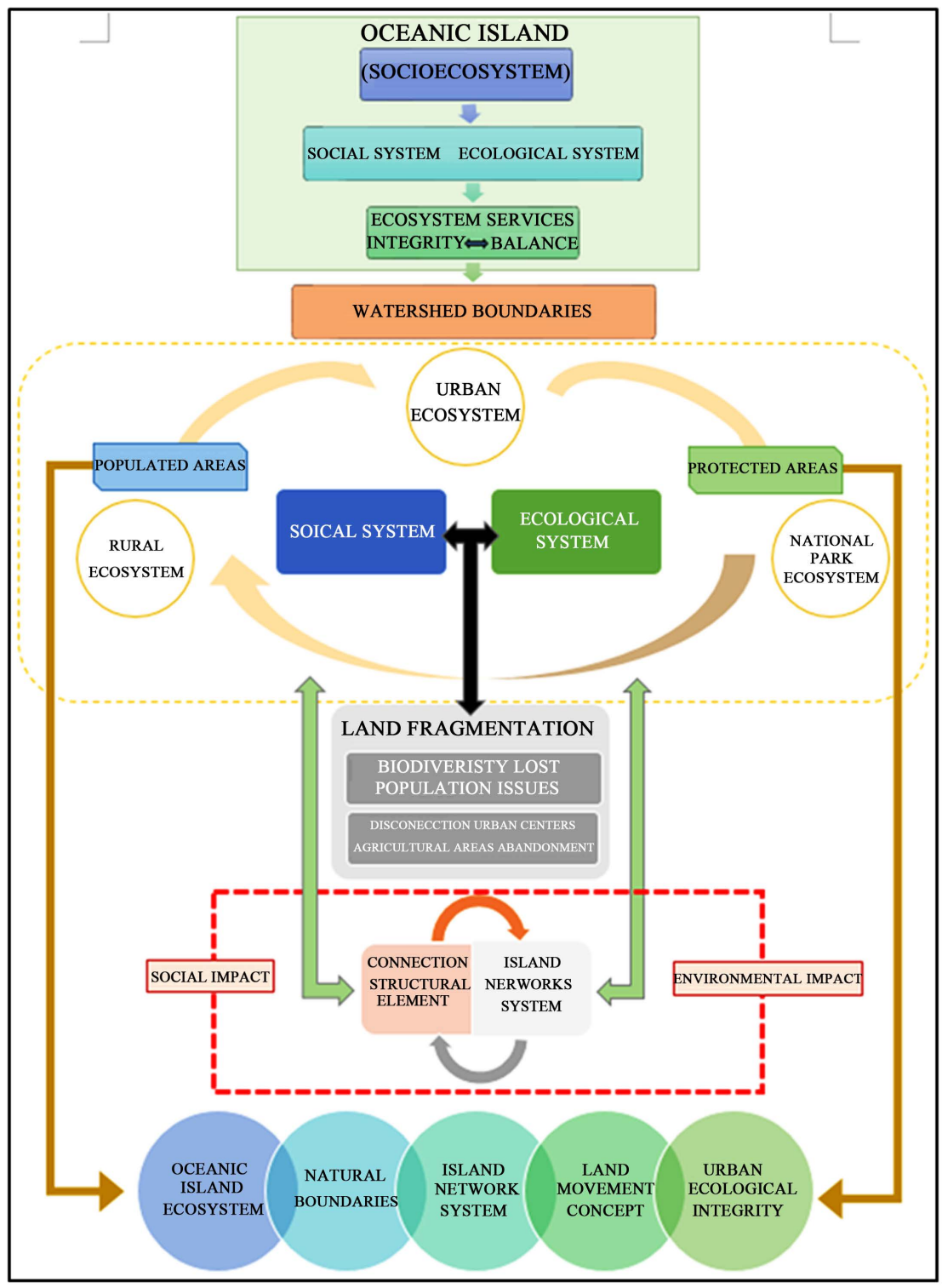

Figure 16. System plan integration approach. 


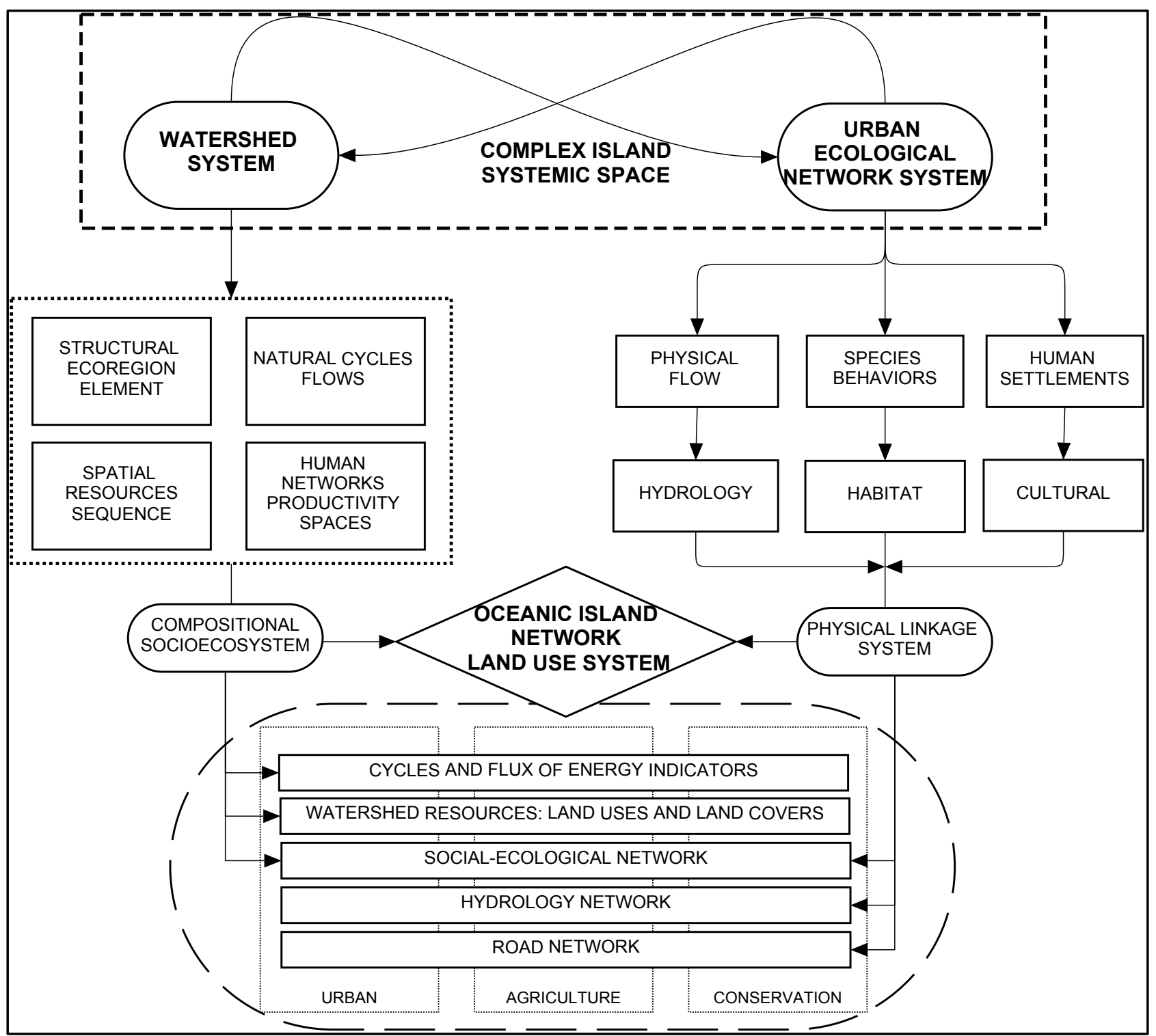

Figure 17. Oceanic island network land use system.

\section{Conclusion}

Living on an oceanic island represents understanding their space and resource constraints, at the same time their natural potential and their relationship with the human environment. It is the place where a system of interactions developed influenced by physical, biological and social patterns, defines the different urban and ecological components between the human space and the natural space whose challenge is to seek the functional connectivity of the different social and environmental processes that form the island ecosystem.

In the process of working on the concept of connectivity, network, systems, island ecosystem and the different components of the human and natural space into oceanic islands, got the result of a new approach for Island land use model. Establishing a new concept of sequential space of interconnected systems works 
together into the watershed matrix space. This concept approach improves connectivity and increases permeability for ecological flows into the human settlements.

This research aimed to establish a system for island landscape focusing on the integration into the hierarchical scale matrix of the island context, determined by the island system about urban ecological networks. Landscape elements show the principal components of socio-ecosystem symbiosis spatial sequence. The island land movement concept is used as a model for re-establishing and ensuring the integrity of the oceanic island systems. This goal achieved through combing the two systems in one complex systemic space determined by the Pelican Bay watershed into the Santa Cruz Island.

As a result, the physical spatial linkage system is demonstrated with the island network land use system. It applied such land use strategy for getting the connectivity of Oceanic Island urban and natural areas. The identification and characterization of the island network system components show in detail the specific parameters will be necessary to take into account for the implementation according to each specific oceanic island territory.

We consider that the research results can be used for planning and designing new island network system integration. This methodology establishes a new island network space, such as typology of strategic land use with properties of connectivity, balance and complementarity. These characteristics are necessary to maintain the functionality of social and ecological processes in the territories of the Oceanic islands.

\section{Funding}

This paper belongs to and is supported by CSC Young Teacher Foundation, No. 201706235051

\section{Conflicts of Interest}

The authors declare no conflicts of interest regarding the publication of this paper.

\section{References}

Alexandre, P., Domínguezb, C., Tomaia, P. F., Chaumontd, C., d'Ozouville, N., Villacís, M., \& Violettea, S. (2012). Quantification of Cloud Water Interception along the Windward Slope of Santa Cruz Island, Galapagos (Ecuador). Agricultural and Forest Meteorology, 161, 94-106. https://doi.org/10.1016/j.agrformet.2012.03.018

Beller, W., D’Ayala, P., \& Hein, P. (Eds.) (2004). Sustainable Development and Environmental Management of Small Islands (Vol. 5, 419 p). Paris: UNESCO and The Parthenon Publishing Group. http://pubs.iied.org/pdfs/7755IIED.pdf

Bennett, G., \& Mulongoy, K. J. (2006). Review of Experience with Ecological Networks, Corridors and Buffer Zones (100 p). Montreal: Secretariat of the Convention on Biological Diversity, Technical Series No. 23.

https://www.cbd.int/doc/publications/cbd-ts-23.pdf 
Calado, H., Fonseca, C., Vergílio, M., Costa, A., Moniz, F., Gil, A., \& Dias, J. A. (2014). Small Islands Conservation and Protected Areas. Journal of Integrated Coastal Zone Management, 14, 167-174.

CDF and WWF (Charles Darwin Foundation and World Wildlife Fund) (2002). A Biodiversity Vision for the Galapagos Islands. Ed. R. Bensted-Smith. Puerto Ayora: CDF.

Connelly, S. (2008). Hawaii Futures, an Intervention for Island Urbanism. AfterOceanic. https://www.hawaii-futures.com/

Cook, E. A. (1991). Urban Landscape Networks: An Ecological Planning Framework. Landscape Research, 16, 7-15. https://doi.org/10.1080/01426399108706345

Cook, E. A. (2002). Landscape Structure Indices for Assessing Urban Ecological Networks. Landscape and Urban Planning, 58, 269-280.

Cook, E. E. A. (2000). Ecological Networks in Urban Landscapes. The Netherlands: Wageningen University. https://library.wur.nl/WebQuery/wda/982402

d'Ozouville N. (2008). Manejo de recursos hídricos: caso de la cuenca de PelicanBay (pp. 158-167). Informe Galápagos 2007-2008.

https://www.researchgate.net/publication/245239223_Manejo_de_recursos_hidricos_c aso_de_la_cuenca_de_Pelican_Bay

d'Ozouville, N. (2007). Agua dulce: la realidad de un recurso crítico (pp. 150-160). Informe Galápagos 2006-2007.

https://www.researchgate.net/publication/245237629_Agua_Dulce_La_Realidad_De_U n_Recurso_Critico

d'Ozouville, N., Benoît, D., Jérôme, B., Urs, W., Sophie, V., de Marsily, G. (2008). DEM Generation Using ASAR (ENVISAT) for Addressing the Lack of Freshwater Ecosystems Management, Santa Cruz Island, Galapagos. Remote Sensing of Environment, 112, 4131-4147.

Dirección del Parque Nacional Galápagos (DPNG) (2014). Plan de Manejo de las Áreas Protegidas de Galápagos para el Buen Vivir. Puerto Ayora, Galápagos, Ecuador. http://www.galapagos.gob.ec/wp-content/uploads/downloads/2016/07/DPNG_Plan_de _Manejo_2014.pdf

Fischer-Kowalski, M., Xenidis, L., Singh, S., \& Pallua, I. (2011). Transforming the Greek Island of Samothraki into a UNESCO Biosphere Reserve. An Experience in Transdisciplinary. Gaia: Okologische Perspektiven in Natur-, Geistes- und Wirtschaftswissenschaften, 20, 181-190.

Forman Richard, T. T., Sperling, D., Bissonette, J., Clevenger, A., Cutshall, C., Dale, V., Fahrig, L., France, R., Goldman, C., Heanue, K., Jones, J., Swanson, F., Turrentine, T., \& Winter, T. (2002). Road Ecology: Science and Solutions. Washington DC, Covelo, London: Island Press.

Forman, R. T. T. (1995). Land Mosaics: The Ecology of Landscapes and Regions. United Kingdom: Cambridge University Press.

Forman, R. T. T. (2014). Urban Ecology: Science of Cities. New York: Cambridge University Press.

Forman, R. T. T., \& Alexander Lauren, E. (1998). Roads and Their Major Ecological Effects. Annual Review of Ecology and Systematics, 29, 207-231. https://pdfs.semanticscholar.org/84c7/9dbc51144030666e6d1d981d27d89602bdca.pdf

Forman, R. T. T., \& Godron, M. (1981). Patches and Structural Components for a Landscape Ecology. BioScience, 31, 733-740.

Gillespie, R. G. (2007). Oceanic Islands: Models of Diversity (pp. 1-13). Encyclopedia of 
Biodiversity, Berkeley, CA: University of California. https://doi.org/10.1016/B978-012226865-6/00517-1

Gobierno Autónomo Descentralizado Municipal de Santa Cruz (GADMSC) (2015). Plan de Desarrollo y Ordenamiento Territorial del Cantón Santa Cruz 2015-2027. http://www.gadsantacruz.gob.ec/wp-content/uploads/2015/09/PDyOT_PagWeb.pdf

González, J. A., Montes, C., Rodríguez, J., \& Tapia, W. (2008). Rethinking the Galapagos Islands as a Complex Social-Ecological System: Implications for Conservation and Management. Ecology and Society, 13, 13. https://doi.org/10.5751/ES-02557-130213 http://www.ecologyandsociety.org/vol13/iss2/art13/

Gottdenker, N. L., Walsh, T., Jiménez-Uzcátegui, G., Betancourt, F., Cruz, M., Soos, C., Eric Miller, R., \& Parker, P. G. (2008). Causes of Mortality of Causes of Mortality of Wild Birds Submitted to the Charles Darwin Research Station, Santa Cruz, Galápagos, Ecuador from 2002-2004. Journal of Wildlife Diseases, 44, 1024-1031.

Grimm, N. B., Grove, J. M., Pickett, S. T. A., \& Redman, C. L. (2000). Integrated Approaches to Long-Term Studies of Urban Ecological Systems. BioScience, 50, 571-584.

Grydehoj, A., \& Kelman, I. (2016). Island Smart Eco-Cities: Innovation, Secessionary Enclaves, and the Selling of Sustainability. Urban Island Studies, 2, 1-24.

https://doi.org/10.20958/uis.2016.1

Guyot-Téphany, J., Grenier, C., Cléder, E., \& Orellana, D. (2013). Uso del espacio y patrones de movilidad en Galápagos. In Informe Galápagos 2011-2012 (pp. 52-58). https://galapagos-es.squarespace.com/s/2012-Informe-Galapagos.pdf

Hamann, O. (1979). On Climatic Conditions, Vegetation Types, and Leaf Size in the Galapagos Islands. Biotropica, 11, 101-122. https://doi.org/10.2307/2387785

Harrison, L. (2016). Connectivity and Ecological Networks. Landscape Institute Technical Information Note. http://www.landscapeinstitute.org

Henderson, S. (2003). Islands. Oxford: Encyclopedia of Life Sciences.

Hess, A. L. (1990). Overview: Sustainable Development and Environmental Management of Small Islands. In W. B. P. D’Ayala, \& P. Hein (Eds.), Sustainable Development and Environmental Management of Small Islands, Sustainable Development and Management of Small Islands (pp. 3-14). Paris: UNESCO, Man and the Biosphere Series 5.

Khatun, K. (2018). Land Use Management in the Galapagos: A Preliminary Study on Reducing the Impacts Invasive Plant Species through Sustainable Agriculture and for Ecosystem Services. Land Degradation and Development, 29, 1-8.

https://doi.org/10.1002/ldr.3003

Kirch, P. (2009). Human Impacts, Pre-European. Gillespie, 8, 414-418. https://www.academia.edu/916260/Human_impacts_on_Oceanic_islands

Lynch, K. (1960). Image of a City. Cambridge: MIT Press.

MacArthur, R. H., \& Wilson, E. O. (1967). The Theory of Island Biogeography (224 p). Princeton, NJ: Princeton University Press.

Mejías, M. A. (2018). The Corridor Island: A New Space to Redesign the Landscape of Tenerife. http://www.intechopen.com/books/urban-agglomeration

Noone, K. J. (2013). Sea-Level Rise. Managing Ocean Environments in a Changing Climate (pp. 97-126).

Nunn, P. D., Veitayaki, J., Ram-Bideshi, V., \& Vinusea, A. (1999). Coastal Issues for Oceanic Islands: Implications for Human Futures. Natural Resources Forum, 23, 195-207. https://doi.org/10.1111/j.1477-8947.1999.tb00909.x

O’Keefe, T. C., Elliot, S. R., \& Naiman, R. J. (1996). Watershed Approach Framework. 
Watershed Academy.

https://www.epa.gov/watershedacademy/watershed-management-publications

Oh, K., Lee, D., \& Park, C. (2011). Urban Ecological Network. Planning for Sustainable Landscape Management. Journal of Urban Technology, 18, 39-59.

https://doi.org/10.1080/10630732.2011.648433

Ospina, P. (2006). Galápagos, naturaleza y sociedad: Actores sociales y conflictos ambientales. Quito: Universidad Andina Simón Bolívar and Corporación Editora Nacional.

Palomo, I., Montes, C., Martín-López, B., González, J. A., García-Llorente, M., Alcorlo, P., \& Rosario, G. M. M. (2014). Incorporating the Social-Ecological Approach in Protected Areas in the Anthropocene. Bio Science, 64, 181-191.

https://academic.oup.com/bioscience/article/64/3/181/224408

Paulay, G. (1994). Biodiversity on Oceanic Islands: Its Origin and Extinction. American Zoologist, 34, 134-144.

https://academic.oup.com/icb/article-pdf/34/1/134/260257/34-1-134.pdf

Pickett, S. T. A., Burch, W. R., Dalton, S. E., Foresman, T. W., Morgan, G. J., \& Rowntree, R. (1997). A Conceptual Framework for the Study of Human Ecosystems in Urban Areas. Urban Ecosystems, 1, 185-199.

https://www.fs.fed.us/nrs/pubs/jrnl/1997/ne_1997_pickett_001.pdf

Plan de Desarrollo y Ordenamiento Territorial 2012-2027. (2012). Santa Cruz Galapagos: GADMSC.

Sauer, J. (1969). Oceanic Islands and Biogeographical Theory: A Review. Geographical Review, 59, 582-593. https://doi.org/10.2307/213863

Taylor, P. D., Fahrig, L., Henein, K., \& Merriam, G. (1993). Connectivity Is a Vital Element of Landscape Structure. Oikos, 68, 571-572. https://doi.org/10.2307/3544927 https://max2.ese.u-psud.fr/epc/conservation/PDFs/HIPE/Taylor1993.pdf

Taylor, P., Fahrig, L., \& With, K. (2006). Landscape Connectivity: A Return to the Basics. In K. Crooks, \& M. Sanjayan (Eds.), Connectivity Conservation, Conservation Biology (pp. 29-43). Cambridge: Cambridge University Press. https://doi.org/10.1017/CBO9780511754821.003

Tischendorf, L., \& Fahrig, L. (2000). On the Usage and Measurement of Landscape Connectivity. Oikos, 90, 7-19. https://doi.org/10.1034/j.1600-0706.2000.900102.x https://pdfs.semanticscholar.org/004a/6fa76f28ccb5376863e721b9f5a632aa2a4c.pdf

Troumbis, A. Y., Farjon, J. M. J., Miklos, L., Mugica, M., \& Jongman, R. H. G. (1995). Buffer Zones and Ecological Corridors. Paris: European Centre for Nature Conservation. https://bd.eionet.europa.eu/publications/ECNC_1995.pdf

United Nations Educational, Scientific and Cultural Organization (UNESCO) (1974). Task Force on Criteria and Guidelines for the Choice and Establishment of Biosphere Reserves. Final Report, MAB Report Series No. 22, Paris: UNESCO.

http://unesdoc.unesco.org/images/0000/000098/009834EB.pdf

United Nations Human Settlements Programme (UN-Habitat) (2015). Urbanization and Climate Change in Small Island Developing States. Nairobi.

https://sustainabledevelopment.un.org/content/documents/2169(UN-Habitat,\%202015 \%20SIDS_Urbanization.pdf

Wong, P. P., Marone, E., Lana, P., \& Fortes, M. (2005). Island Systems. In Ecosystems and Human Well-Being: Current State and Trends (Chapter 23, 663-680). Washington DC: Island Press.

https://www.millenniumassessment.org/documents/document.292.aspx.pdf 
Xiu, N., Ignatieva, M., \& Konijnendijk van den Bosch, C. (2016). The Challenges of Planning and Designing Urban Green Networks in Scandinavian and Chinese Cities. Journal of Architecture and Urbanism, 40, 163-176.

https://doi.org/10.3846/20297955.2016.1210047 